\title{
Potential toxic elements in stream sediments, soils and waters in an abandoned radium mine (central Portugal)
}

\author{
I. M. H. R. Antunes - A. M. R. Neiva - M. T. D. Albuquerque - P. C. S. Carvalho \\ A. C. T. Santos $\cdot$ Pedro P. Cunha
}

Received: 18 December 2016/ Accepted: 17 March 2017

(C) Springer Science+Business Media Dordrecht 2017

\begin{abstract}
The Alto da Várzea radium mine (AV) exploited ore and U-bearing minerals, such as autunite and torbernite. The mine was exploited underground from 1911 to 1922, closed in 1946 without restoration, and actually a commercial area is deployed. Stream sediments, soils and water samples were collected between 2008 and 2009. Stream sediments are mainly contaminated in As, Th, $\mathrm{U}$ and $\mathrm{W}$, which is related to the AV radium mine. The PTEs, As, $\mathrm{Co}, \mathrm{Cr}, \mathrm{Sr}, \mathrm{Th}, \mathrm{U}$, $\mathrm{W}, \mathrm{Zn}$, and electrical conductivity reached the highest values in soils collected inside the mine influence. Soils are contaminated with As and $\mathrm{U}$ and must not be
\end{abstract}

I. M. H. R. Antunes ( $₫)$

ICT Centre / University of Minho, Braga, Portugal

e-mail: imantunes@dct.uminho.pt

I. M. H. R. Antunes - M. T. D. Albuquerque

CERENA Centre, Porto, Portugal

A. M. R. Neiva

GEOBIOTE Centre, Aveiro, Portugal

A. M. R. Neiva - P. C. S. Carvalho - A. C. T. Santos Department of Earth Sciences, University of Coimbra, Coimbra, Portugal

M. T. D. Albuquerque

Instituto Politécnico de Castelo Branco, Castelo Branco,

Portugal

P. P. Cunha

MARE - Marine and Environmental Sciences Centre,

University of Coimbra, Coimbra, Portugal used for any purpose. Most waters have $\mathrm{pH}$ values ranging from 4.3 to 6.8 and are poorly mineralized $(\mathrm{EC}=41-186 \mu \mathrm{S} / \mathrm{cm} ; \quad \mathrm{TDS}=33-172 \mathrm{mg} / \mathrm{L})$. Groundwater contains the highest $\mathrm{Cu}, \mathrm{Cr}$ and $\mathrm{Pb}$ contents. Arsenic occurs predominantly as $\mathrm{H}_{2}\left(\mathrm{AsO}_{4}\right)^{-}$ and $\mathrm{H}\left(\mathrm{AsO}_{4}\right)^{2-}$. Waters are saturated in goethite, haematite and some of them also in lepidocrocite and ferrihydrite, which adsorbs As (V). Lead is divalent in waters collected during the warm season, being mobile in these waters. Thorium occurs mainly as $\mathrm{Th}(\mathrm{OH})_{3}(-$ $\left.\mathrm{CO}_{3}\right)^{-}, \mathrm{Th}(\mathrm{OH})_{2}\left(\mathrm{CO}_{3}\right)$ and $\mathrm{Th}(\mathrm{OH})_{2}\left(\mathrm{CO}_{3}\right)_{2}^{2-}$, which increase water Th contents. Uranium occurs predominantly as $\mathrm{UO}_{2} \mathrm{CO}_{3}$, but $\mathrm{CaUO}_{2}\left(\mathrm{CO}_{3}\right)_{3}^{2-}$ and $\mathrm{CaUO}_{2}(-$ $\left.\mathrm{CO}_{3}\right)_{3}$ also occur, decreasing its mobility in water. The waters are contaminated in $\mathrm{NO}_{2}{ }^{-}, \mathrm{Mn}, \mathrm{Cu}, \mathrm{As}, \mathrm{Pb}$ and $\mathrm{U}$ and must not be used for human consumption and in agricultural activities. The water contamination is mainly associated with the old radium mine and human activities. A restoration of the mining area with PTE monitoring is necessary to avoid a public hazard.

Keywords Radium mines - Enrichment factor · Contamination $\cdot$ Remediation $\cdot$ Central Portugal

\section{Introduction}

Mining activity is considered as one of the most potentially harmful anthropogenic activities in the world (Acosta et al. 2011) and its disruptive effects on 
the environment have been known for decades. In general, mining activities are associated with waste production and the disposal of mine wastes often produces more environmental problems than the mining operations themselves (e.g. Fernandez-Caliani et al. 2009).

In Portugal, between 1908 and 2001, about 60 radioactive ore deposits were extracted for the production of radium and uranium (Carvalho 2014). Following closure, the Portuguese mines were abandoned and local areas of former radium and uranium mines were studied for environmental radioactivity, metals and public health impact (e.g. Pinto et al. 2004; Antunes and Albuquerque 2013; Carvalho et al. 2013; Carvalho 2014; Neiva et al. 2014, 2015, 2016a).

The extraction of radioactive ore produces tailings, large volumes of contaminated waste rocks and heapleach residues accumulated in the dumps at mine sites. The discharges of uranium and associated heavy metals and metalloids from waste and tailing dumps in abandoned uranium mining and processing sites pose contamination risks to environment and human health (e.g. Albuquerque and Antunes 2015; Neiva et al. 2016a, b) with a significant amount of potentially toxic elements (PTEs) (Acosta et al. 2011; Favas et al. 2011). PTEs may be transferred from mining areas to nearby stream sediments, soils and waters by drainage and/or atmospheric deposition; thus, abandoned mines are one of the most important sources of contamination (e.g. Siegel 2002; Ferreira da Silva et al. 2004; Boularbah et al. 2006). In recent years, pollution of stream sediments and soils by PTEs in areas adjacent to mine sites has been reported in many countries (e.g. Cui and Xin 2011; Vrhovnik et al. 2013; Neiva et al. 2016b).

The main purpose of this study is to characterize the spatial and temporal geochemistry of selected PTEs in stream sediments, soils, surface water and groundwater associated with the old mine of Alto da Várzea, 65 years after closure. The obtained results will allow assessing the potential toxic contamination and environmental risks associated with the abandoned radium mine and to improve remediation processes in the study area and avoid similar problems in other mine areas.

\section{Alto da Várzea mine area}

The Alto da Varzea radium mine (AV mine) area is located at the Central Iberian Zone of the Iberian
Massif (ZCI), located at the southeastern of the town of Guarda (central Portugal) (Fig. 1a). In this area, a Variscan porphyritic two-mica granite occurs and intruded the Beiras Group (previously called Schistgreywacke complex) (EDM 2005). The mine is in a low slope area with altitudes ranging from 810 to $840 \mathrm{~m}$.

The mineralization occurs in quartz veins trending $\mathrm{N} 25-30^{\circ} \mathrm{E} / \mathrm{SW}$, up to $5 \mathrm{~m}$ thick at depth associated with weathered granite and jasper veins. These veins contain secondary U-minerals such as autunite $\left(\mathrm{Ca}\left(\mathrm{UO}_{2}\right)_{2}\right.$ $\left.\left(\mathrm{PO}_{4}\right)_{2} \cdot 10-12 \mathrm{H}_{2} \mathrm{O}\right)$ and torbernite $\left(\mathrm{Cu}\left(\mathrm{UO}_{2}\right)_{2}\left(\mathrm{PO}_{4}\right)_{2-}\right.$ $\left.11 \mathrm{H}_{2} \mathrm{O}\right)(\mathrm{EDM} 2005)$.

The mine exploited radium retained in ore minerals and was exploited mainly underground, with three levels at 25, 50 and $75 \mathrm{~m}$, respectively, and a gallery at the hillside. The mine exploitation occurred between 1911 and 1922 (Enterprise: Minaru Lda) and was closed in 1946. The mine area was not restored and actually a commercial area is deployed.

The Alto da Várzea area is characterized by a warm and temperate climate with a Csb type, according to the Köppen and Geiger classification (IPMA 2015). The average annual precipitation is $892 \mathrm{~mm}$. There is more rainfall in winter than in summer, with a gap of $236 \mathrm{~mm}$ rainfall between the driest month and the wettest month. The wet season starts in October and lasts until May and the mean annual temperature is $10.7{ }^{\circ} \mathrm{C}$. In August, the hottest month of the year has an average temperature of $39.4{ }^{\circ} \mathrm{C}$, while in January is about $3.5^{\circ} \mathrm{C}$, according to the data of the Guarda weather station, central Portugal (SNIRH 2009).

The hydrology of the area is dominated by the Diz stream that is an effluent of the right bank of Côa river, belonging to the catchment area of the Douro river. The surface drainage runs to SE towards the Diz stream which has a very low water flux in the summer. One dump retained the waste from the mine exploration and contained about 2000 ton of leached materials without any compaction.

The area has rural characteristics and is covered by vegetation, consisting mostly of oaks, pasture and agricultural zones, located around the old mine. The industry is reduced; however, the waste water treatment plant is not efficient and uncontrolled domestic and industrial discharges wastes are an important source of the Diz river contamination. 


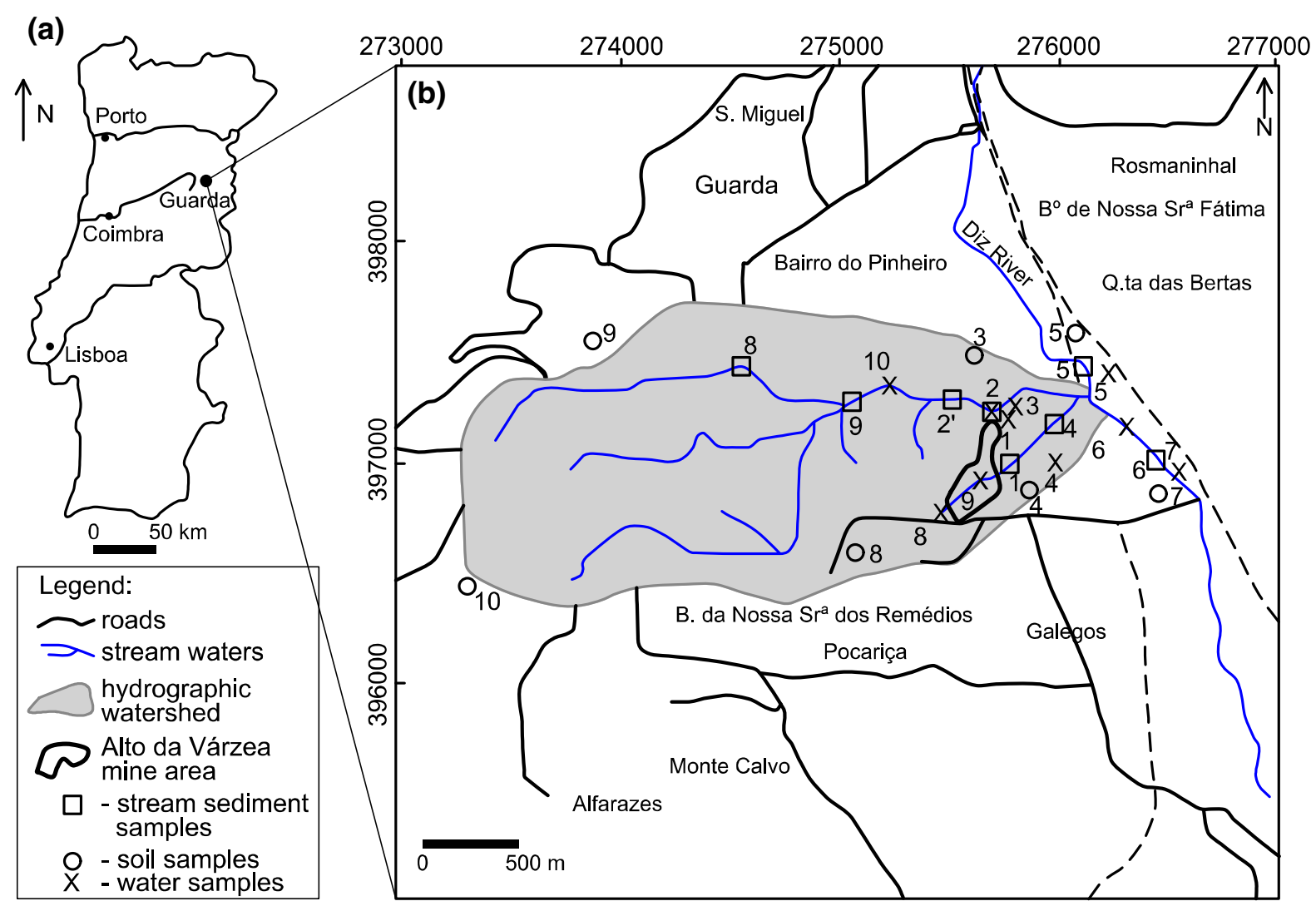

Fig. 1 a Location of the Alto da Várzea (AV) radium mine on the map of Portugal; b hydrographic stream watershed and location of soil, stream sediment and water sample sites

\section{Material and methodology}

A total of 8 stream sediment samples, with 2 of them upstream and 6 downstream of the Alto da Várzea radium mine area were collected. A total of 7 soil samples was also collected, including 2 from an adjacent area outside the mine influence and 5 from inside the area that received the mine influence. The soil samples were collected at a depth between 20 and $30 \mathrm{~cm}$ in April 2009. Stream sediments and soil samples were collected in a granitic bedrock. The samples were transported in polyethylene bags, dried at $40{ }^{\circ} \mathrm{C}$, disaggregated with a rubber hammer and sieved through a $2 \mathrm{~mm}$ nylon sieve. The $\mathrm{pH}$ was measured in a solid-water suspension with a liquid/solid ratio of 2.5. The electrical conductivity (EC) was measured in a liquid/solid rate of $1 / 5$. The $<250 \mu \mathrm{m}$ fraction of stream sediment and soil samples were digested with aqua regia $(3: 1 \mathrm{HCl}-$ $\mathrm{HNO}_{3}$ ), filtered through a $2 \mu \mathrm{m}$ filter and analysed by ICP-OES, using a Horiba Jobin-Yvon JY-2000 2 spectrometer with a monochromator to determine metals and metalloids. The certified sewage sludgeamended soil BCR 143R was used to validate an internal reference soil, prepared with aqua regia. A laboratory standard and duplicate blanks were included at the beginning and the end of 15 analysed samples. The accuracy and precision were determined using the same methodology for water samples. The obtained results were accepted if they were lower than those shown in Table 1 . The detection limits in $\mathrm{mg} / \mathrm{kg}$ are 0.83 for As, 1.7 for $\mathrm{Sb}, 2.6$ for $\mathrm{Sr}, 2.8$ for Th, $\mathrm{U}$ and W, 3.0 for $\mathrm{Cr}$ and $\mathrm{Ni}, 3.2$ for $\mathrm{Fe}, 3.3$ for $\mathrm{Mn}, 3.5$ for $\mathrm{Cd}$, 3.6 for $\mathrm{Co}, 4.0$ for $\mathrm{Al}$ and $\mathrm{Pb}, 4.1$ for $\mathrm{Cu}$ and 4.9 for $\mathrm{Zn}$. All the data were obtained at the Department of Earth Sciences, University of Coimbra, Portugal. 
Table 1 Allowance of accuracy and precision for routine analysis

\begin{tabular}{|c|c|c|}
\hline Concentration range & $\frac{\text { Accuracy }}{\Delta \lg C=\left|\lg \bar{C}_{i}-\lg C_{s}\right|}$ & $\begin{array}{l}\text { Precision } \\
\lambda=\sqrt{\frac{\sum_{i=1}^{n}\left(\lg C_{i}-\lg C_{s}\right)^{2}}{n-1}}\end{array}$ \\
\hline \multicolumn{3}{|l|}{ Water } \\
\hline$<3$ Detection limit & $\leq 0.29$ & 0.43 \\
\hline$>3$ Detection limit & $\leq 0.12$ & 0.16 \\
\hline \multicolumn{3}{|c|}{ Stream sediment and soil } \\
\hline$<3$ Detection limit & $\leq 0.067$ & 0.062 \\
\hline$>3$ Detection limit & $\leq 0.042$ & 0.059 \\
\hline
\end{tabular}

$\bar{C}_{i}$, the average determined value of the standards Relacre ${ }_{i}$ for water and $B C R_{t}$ for stream sediment and soil; $C_{i}$, the determined value of the standards Relacre for water and BCR for stream sediment and soil; $C_{s}$, the recommended value of the standards Relacre for water and BCR for stream sediment and soil; $n$, number of standard subsamples located within each batch of samples

Cation exchange capacity (CEC) and organic matter $(\mathrm{OM})$ were determined in 3 representative stream sediment samples and 3 soil samples (upstream the mine influence and downstream the mine influence), with the highest $\mathrm{U}$ and Th concentrations, at the Department of Soils and Plants, University of Trás-os-Montes and Alto Douro (UTAD), Portugal. CEC was determined according to the method of Thomas (1982). It is the sum of extractable bases and extractable acidity by the ammonium acetate solution $(\mathrm{pH} 7)$ with a precision of $0.4 \%$. The organic carbon content was determined using an elemental analyzer. $\mathrm{CO}_{2}$ was quantified by an NIRD (near infrared detector), after oxidation at $1100{ }^{\circ} \mathrm{C}$, and $\mathrm{CO}_{2}$ was converted into $\mathrm{C}$. Assuming that $\mathrm{OM}$ contains 58\% organic carbon (Nelson and Sommers 1996), the organic matter (OM) was calculated applying a factor of 1.724 to the $\mathrm{C}$. The precision was of $1.8 \%$.

The grain size distribution and textural characteristics were obtained in the same 3 stream sediment and 3 soil samples, where CEC was determined, at the Department of Earth Sciences, University of Coimbra, Portugal. The grain distribution of the fraction $<2 \mathrm{~mm}$ of these samples was obtained by laser diffraction analysis, with a Coulter laser granulometer $(2 \mathrm{~mm}-$ $0.04 \mu \mathrm{m}$ ) with a precision up to $5 \%$. The mineralogical identification of clay minerals in the $<2 \mu \mathrm{m}$ fraction in oriented samples, before and after treatments with ethylene glycol and heating up to $550{ }^{\circ} \mathrm{C}$, was carried out with a Philips $3710 \mathrm{X}$-ray diffractometer, with a $\mathrm{Cu}$ tube, at $40 \mathrm{kV}$ and $20 \mathrm{nA}$.

A total of ten sampling points was chosen to collect water samples four times, in summer (July 2008 and
2009), winter (January 2009) and spring (April 2009), obtaining a total of 35 water samples. One sampling point received drainage water from: a mine dump (sample AV1), a mine gallery (sample AV2) and a spring (AV5), three water samples were obtained in wells (samples AV3, AV4 and AV7) and streams (samples AV8, AV6 and AV9). These nine water samples are considered inside the mine influence area (the area affected by the mine exploitation). One water sample was collected upstream the mine area and is considered outside the mine influence area (sample AV10) (Fig. 1b). Water samples were collected about $20 \mathrm{~cm}$ below the surface of the water level. Temperature, $\mathrm{pH}$, Eh, dissolved oxygen (DO), electrical conductivity (EC) and alkalinity were measured in situ. The samples were filtered through $0.45-\mu \mathrm{m}$ pore-size membrane filters. The determinations were carried out in the Department of Earth Sciences, University of Coimbra (Portugal). Cations were determined by inductively coupled plasma optical emission spectrometry (ICP-OES; Horiba Jovin Yvon JV2000 2 spectrometer with a monochromator), in $\mathrm{HNO}_{3}$ acidified samples with ( $\mathrm{pH}$ 2), while anions were determined in non-acidified samples by ion chromatography (Dionex ICS 3000 Model). The detection limits in $\mu \mathrm{g} / \mathrm{L}$ were 0.01 for $\mathrm{K}, \mathrm{Ca}$ and $\mathrm{Th}$; 0.02 for $\mathrm{Na}, \mathrm{Al}, \mathrm{Pb}, \mathrm{Ni}$, As and $\mathrm{U} ; 0.22$ for $\mathrm{Sr}$; 0.38 for $\mathrm{Li} ; 1.43$ for $\mathrm{Mn}$; 1.47 for B; 1.54 for $\mathrm{Co}$; 1.92 for $\mathrm{Zn}$; 2.1 for $\mathrm{Cr}$; 2.2 for $\mathrm{Cu}$ and $\mathrm{Cd} ; 2.8$ for $\mathrm{Ba} ; 3.2$ for $\mathrm{Fe}$; 5.76 for $\mathrm{Mg}$; 0.93 for $\mathrm{F}^{-} ; 1.32$ for $\mathrm{Cl}^{-} ; 1.20$ for $\mathrm{NO}_{2}{ }^{-}$; 1.37 for $\mathrm{NO}_{3}{ }^{-} ; 2.27$ for $\mathrm{SO}_{4}{ }^{2-}$ and 1.19 for $\mathrm{PO}_{4}{ }^{3-}$. The accuracy and precision for water analysis were obtained by inserting two subsamples of an external standard (Relacre, report EAA.2007Fev.V0) within 
each batch of ten water samples, and the calculations were taken according to defined methodologies (Xuejing 1995; Min et al. 2014). Total dissolved solids (TDS) resulted in the weight of material by evaporating $100 \mathrm{~mL}$ of filtered water. Ion balance errors of the analytical data were less than $\pm 10 \%$ for most water samples.

The modelling of $\mathrm{As}, \mathrm{Pb}$, Th and $\mathrm{U}$ in water samples with the highest concentrations of these elements was carried out using the software Phreeq $\mathrm{C}$ and the ThermoChimie database (Andra 2009; Parkhurst and Appelo 2013).

\section{Results and discussion}

Geochemistry of stream sediments and soils

The textural characteristics, physical-chemical parameters, and concentrations of PTEs in stream sediments from the old Alto da Várzea radium mine area are given in Table 2a. The stream sediments contain mainly sand. The clay size fraction $(<4 \mu \mathrm{m})$ is up to $2.7 \%$. The $<2 \mu \mathrm{m}$ clay size fraction contains illite, kaolinite and vermiculite. The $\mathrm{pH}$ values are of 5.8-6.8 in upstream sediments and 4.2-6.6 in downstream sediments (Table 2a). The electrical conductivity (EC) ranges from 54 to $107 \mu \mathrm{S} / \mathrm{cm}$ in upstream sediments and ranges between 28 and $243 \mu \mathrm{S} / \mathrm{cm}$, but presents only one value of $499 \mu \mathrm{S} / \mathrm{cm}$ in downstream sediments, suggesting that the contamination is low. The CEC values are of $2.1-2.5$ and $9.6 \mathrm{cmol} / \mathrm{kg}$ in upstream and downstream sediments, respectively. The OM values are also low of $0.31-0.93 \%$ in upstream sediments and $2.8 \%$ in downstream sediments.

In general, the downstream sediments have higher $\mathrm{Fe}, \mathrm{As}, \mathrm{Pb}, \mathrm{U}$ and $\mathrm{W}$ concentrations than the upstream sediments (Fig. 2; Table 2a) due to erosion and leaching of the mine dumps. The OM content and clay size fraction of stream sediments are low to have retained any significant concentration of PTEs. The Fe concentration is up to $25.0 \mathrm{~g} / \mathrm{kg}$. Probably $\mathrm{As}, \mathrm{Pb}$ and $\mathrm{U}$ are adsorbed by $\mathrm{Fe}$-oxyhydroxides, as in other uranium mine areas (e.g. Pinto et al. 2004; Cabral Pinto et al. 2008, 2009; Carvalho et al. 2012; Larios et al. 2012).

The physical-chemical parameters and concentration of PTEs of soils from the old Alto da Várzea radium mine area are presented in Table $2 \mathrm{~b}$. The soils are dominantly cambisols (Cardoso et al. 1973) and were not considered evolved soils. However, these soils are suitable for pasture and forest occupation and/ or agricultural potential (European Environment Agency 2006).

The soils present similar textural characteristics as stream sediments. The soils contain mainly fine-sand and the clay size fraction $(<4 \mu \mathrm{m})$ is up to $8.5 \%$. The $<2 \mu \mathrm{m}$ clay size fraction contains illite, kaolinite and vermiculite. The soils from the study area have a local agricultural activity but in general, presented a lower OM content (up to $3.12 \%$ ). The CEC values are of $4.0-4.8$ and $10.2 \mathrm{cmol} / \mathrm{kg}$ in soil samples collected outside and inside mine influence area, respectively (Table 2b).

These soils are neutral to acidic with values of 4.9-5.0 and 4.9-5.7 in soil samples collected outside and inside the mine influence, respectively, mainly due to the influence of the granite. Metals are more mobile and more available in more acid than neutral conditions (Alloway 1995).

The maximum concentrations of PTEs-As (130 mg/kg), Co (6.3 mg/kg), Cr (22.6 mg/kg), Mn (956 mg/kg), Sb (5.0 mg/kg), Sr (19.2 mg/kg), Th $(118 \mathrm{mg} / \mathrm{kg}), \mathrm{W}(17.4 \mathrm{mg} / \mathrm{kg})$ and $\mathrm{Zn}(141 \mathrm{mg} / \mathrm{kg})$ are higher in soil samples from inside mine influence than in the soil samples from outside this influence (Fig. 3; Table 2b). These soils collected inside mine influence contain the highest EC $(171 \mu \mathrm{S} / \mathrm{cm})$, because PTE were released from the mine dumps and retained in the closest soils. Otherwise, $\mathrm{Fe}$ and $\mathrm{Mn}$ concentrations in soils collected inside mine influence were within the range measured in the background soil samples but with the highest maximum contents (Table 2b). CEC is related to the amount of $\mathrm{Fe}$ and $\mathrm{Mn}$ hydroxides of soils (Forghani et al. 2015), which played an important adsorption role in the studied soils, as clay minerals occur in a small amount (Table 2 b).

Geochemistry of surface water and groundwater

The abandoned mining area is located close to a rural area, and some of its water is used for agricultural irrigation. Physical-chemical parameters and chemical analyses of water samples from the studied area are given in Table 3. The water sample AV1 was collected just in January 2008, because after that the area was remobilized and this water point disappeared. 


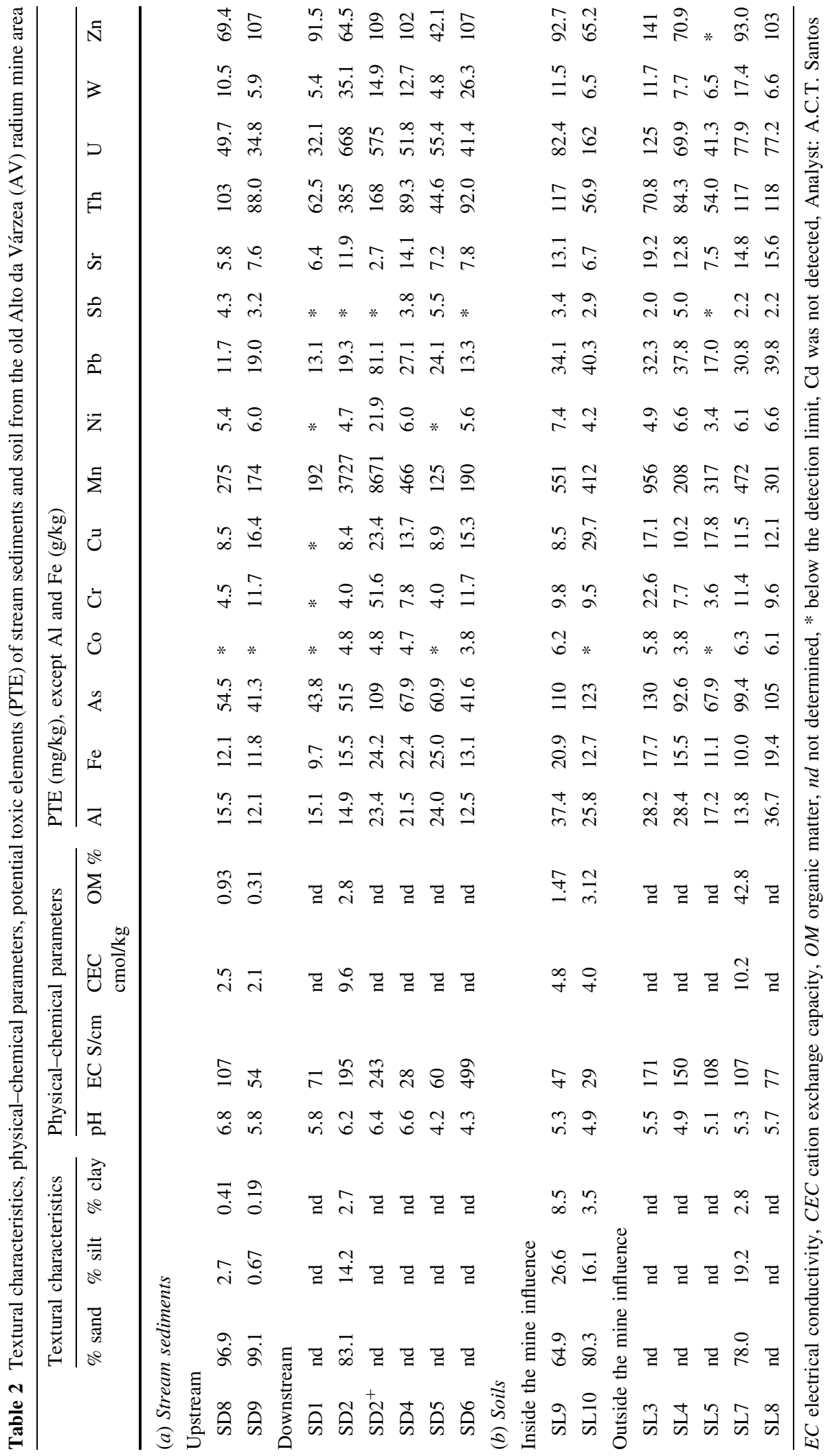



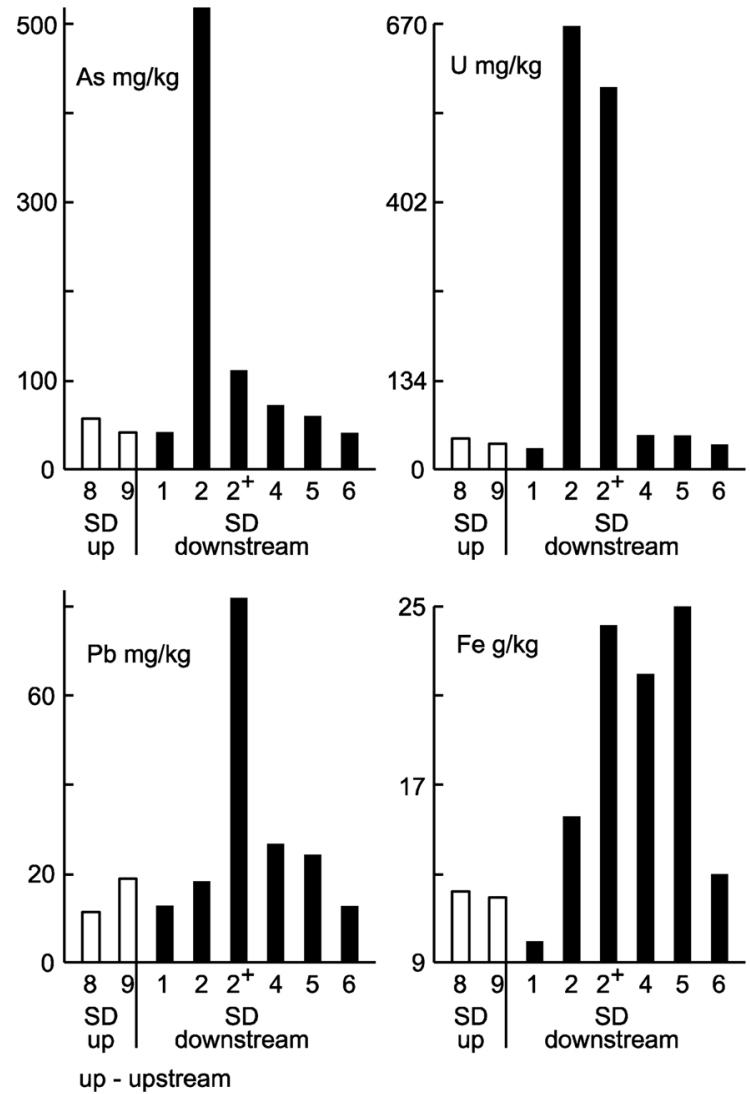

Fig. 2 Arsenic, $\mathrm{U}, \mathrm{Pb}$ and $\mathrm{Fe}$ concentrations in stream sediments (SD) from upstream and downstream of the Alto da Várzea radium mine

In general, the water collected inside mine influence contains the highest $\mathrm{NO}_{2}{ }^{-}, \mathrm{SO}_{4}{ }^{2-}, \mathrm{PO}_{4}{ }^{3-}$, $\mathrm{HCO}_{3}{ }^{-}, \mathrm{Na}, \mathrm{K}$ and PTEs concentrations than the local background due to erosion and leaching of the mine dumps (Table 3). The water carried the PTEs and is responsible for the transport of contamination offsite (Larson et al. 2012). However, there are no significant differences between water sample collected outside mine influence (water sample AV10) and the water samples located inside the mine influence area (Table 3).

The $\mathrm{pH}$ values ranged from 4.3 to 6.8 with more acidic values during summer than winter. The acidic waters resulted of sulphides oxidation from the mineralized veins and consequently from tailings and dumps. The acidic water formed by the oxidation of sulphides is corrosive and causes the leaching of PTEs (e.g. $\mathrm{Ca}, \mathrm{Mg}, \mathrm{Al}$ and $\mathrm{Li}$ ) and $\mathrm{F}^{-}$from the host rocks (Antunes et al. 2016). The Eh values vary from 197 to $476 \mathrm{mV}$. Most waters are poorly mineralized (EC $=41-209 \mu \mathrm{S} / \mathrm{cm}$ ), which was also supported by the total dissolved solids (TDS), ranging from 33 to $172 \mathrm{mg} / \mathrm{L}$. The highest EC and TDS occur in a stream water (water sample AV6: $\mathrm{EC}=636 \mu \mathrm{S} / \mathrm{cm}$ and TDS $=352 \mathrm{mg} / \mathrm{L}$ ) and in a well (water sample AV7: $\mathrm{EC}=397 \mu \mathrm{S} / \mathrm{cm}$ and $\mathrm{TDS}=236 \mathrm{mg} / \mathrm{L})$, which receives drainage from domestic and agricultural activities.

In general, stream waters reach higher $\mathrm{CE}$ values, $\mathrm{Cl}^{-}, \mathrm{NO}_{2}{ }^{-}, \mathrm{NO}_{3}{ }^{-}, \mathrm{SO}_{4}{ }^{2-}, \mathrm{PO}_{4}{ }^{3-}, \mathrm{HCO}_{3}{ }^{-}, \mathrm{Ca}, \mathrm{Mg}$, $\mathrm{Na}, \mathrm{K}, \mathrm{Fe}, \mathrm{Mn}, \mathrm{Zn}$, TDS and TS contents than groundwaters (wells and spring), because they are the most influenced by the seasonal climate conditions and domestic and agricultural activities. However, groundwater samples contain the highest $\mathrm{Cu}$ (up to $77.2 \mu \mathrm{g} / \mathrm{L}$; sample AV5), $\mathrm{Cr}$ (up to $8.2 \mu \mathrm{g} / \mathrm{L}$; sample AV4) and $\mathrm{Pb}$ (up to $50.7 \mu \mathrm{g} / \mathrm{L}$; sample AV5) contents which could be related to the dissolution from underground mineralized quartz veins. There are no significant differences in As (up to $32.8 \mu \mathrm{g} / \mathrm{L}$; sample AV7), Th (up to $4.9 \mu \mathrm{g} / \mathrm{L}$; sample AV7 and AV8) and $\mathrm{U}$ (up to $57.7 \mu \mathrm{g} / \mathrm{L}$; sample AV7 and AV6) contents from surface water and groundwater (Table 3). However, in general, the water from a spring (AV5) is the poorest mineralized water containing the lowest range EC value $(41-58 \mu \mathrm{S} / \mathrm{cm})$ and $\mathrm{Cl}^{-}(6.3-9.4 \mu \mathrm{g} / \mathrm{L})$, $\mathrm{NO}_{2}{ }^{-} \quad(0.35-0.91 \mu \mathrm{g} / \mathrm{L}), \quad \mathrm{NO}_{3}{ }^{-} \quad(0.06-1.2 \mu \mathrm{g} / \mathrm{L})$, $\mathrm{SO}_{4}{ }^{2-}(1.1-1.5 \mu \mathrm{g} / \mathrm{L}), \mathrm{HCO}_{3}{ }^{-}(6.6-10.4 \mu \mathrm{g} / \mathrm{L}), \mathrm{Ca}$ (1.0-1.4 $\mu \mathrm{g} / \mathrm{L}), \mathrm{Mg}(0.39-0.59 \mu \mathrm{g} / \mathrm{L}), \mathrm{Na}(5.2-6.1$ $\mu \mathrm{g} / \mathrm{L}), \mathrm{K}(0.52-0.74 \mu \mathrm{g} / \mathrm{L}), \mathrm{Mn}(7.4-11.5 \mu \mathrm{g} / \mathrm{L}), \mathrm{Ni}$ $(0.4-7.1 \mu \mathrm{g} / \mathrm{L}), \operatorname{Sr}(6.6-11.5 \mu \mathrm{g} / \mathrm{L})$, As $(1.3-13.5 \mu \mathrm{g} /$ $\mathrm{L})$ and $\mathrm{U}(1.3-55.0 \mu \mathrm{g} / \mathrm{L})$ contents but the highest $\mathrm{Al}$ (up to $85.4 \mu \mathrm{g} / \mathrm{L}$ ), $\mathrm{Li}$ (up to $13.0 \mu \mathrm{g} / \mathrm{L}$ ) and $\mathrm{Pb}$ (up to $50.7 \mu \mathrm{g} / \mathrm{L}$ ) contents (Table 3).

Most water samples have low metal concentrations and are classified as neutral-metal poor to acid-metal poor (Fig. 4). According to the Piper classification, most water samples were of undefined type or $\mathrm{Na}-$ $\mathrm{HCO}_{3}{ }^{-}$type. The water from mine gallery (AV2) tends to present the highest contents of $\mathrm{F}^{-}$(up to $0.31 \mathrm{mg} / \mathrm{L}$ ), $\mathrm{Li}$ (up to $58 \mu \mathrm{g} / \mathrm{L}$ ), Mn (up to $1450 \mu \mathrm{g} / \mathrm{L}$ ) and $\mathrm{U}$ (up to $66 \mu \mathrm{g} / \mathrm{L}$ ) (Table 3). In general, there is an increase in U water contents in April and July 2009 due to evaporation and lower $U$ contents during January 2009, probably due to a dilution effect. There is not a significant seasonal variation in the major ion concentrations and PTEs (Table 3). There are no 

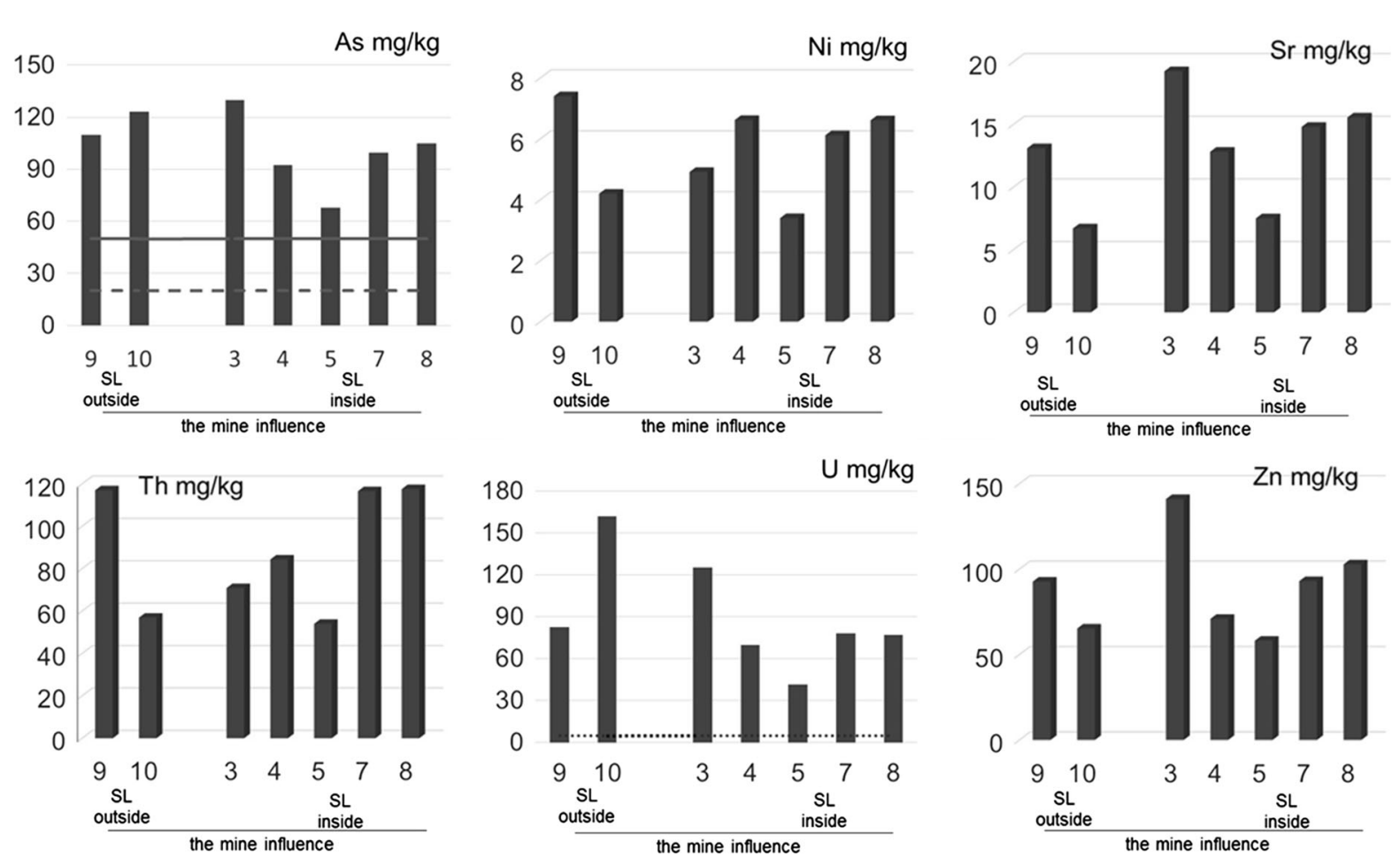

Fig. 3 Selected values of potential toxic elements of soils collected outside mine influence (SL up) and outside the influence (SL downstream) of the Alto da Várzea radium mine. Maximum values for dashed lines public, private green areas

and residential sites; solid lines industrial areas (Decreto Ministeriale 1999); dotted lines U contamination value (Ribera et al. 1996)

significant differences in As, Th and U contents from surface water and groundwater.

Water compositions from Alto da Várzea mine area was plotted in the $\mathrm{Eh}-$ ph for the system As-Fe-O-H-S and all samples fall in the $\mathrm{H}_{2} \mathrm{AsO}_{4}{ }^{-}$field stability because they have a similar range for $\mathrm{Eh}$ and $\mathrm{pH}$ values (Fig. 5).

Speciation of $\mathrm{As}, \mathrm{Pb}$, Th and $\mathrm{U}$ in surface waters and groundwaters

Arsenic occurs as pentavalent species in waters from old Alto da Várzea mine, mainly as $\mathrm{H}_{2}\left(\mathrm{AsO}_{4}\right)^{-}$(up to $98.46 \%)$, but also as $\mathrm{H}\left(\mathrm{AsO}_{4}\right)^{2-}(48.75 \%)$ (Table 4), the less toxic and mobile form of arsenic (Hughes et al. 2011). It also formed small proportions of calciumarsenic complexes $\mathrm{Ca}\left(\mathrm{HAsO}_{4}\right.$ ) (up to $1.40 \%$ ) in some waters (AV2, AV7 and AV6), due to their high $\mathrm{Ca}$ concentrations (Table 3). The waters AV10 (April 2009), AV1 (July 2009), AV2 (April 2009), AV7 (April and July 2009) and AV6 (July 2009) are saturated in ferrihydrite, goethite, haematite and lepidocrocite. Pentavalent arsenic has high affinity to be adsorbed by oxyhydroxides, which reduces its mobility in solution (Mamindy-Pajany et al. 2009). Waters AV10 (July 2009) and AV2 (July 2009) are saturated in crystalline $\mathrm{Cr}_{2} \mathrm{O}_{3}$ (cr), goethite and haematite. AV7 and AV5 (in July 2009) are also saturated in $\mathrm{Cr}_{2} \mathrm{O}_{3}$. AV1, AV7 and AV6, all of them collected in July 2009, are also saturated in trevorite $\left(\mathrm{NiFe}_{2} \mathrm{O}_{4}\right)$.

Lead mainly occurs as divalent form in water samples AV10, AV2 and AV5 all of them collected in July 2009, due to their $\mathrm{pH}$ values lower than 6.0 (Tables 3, 4). In these waters the mobility and bioavailability of $\mathrm{Pb}$ is high. However, in some waters (AV2, AV7, AV6 in April 2009), $\mathrm{PbCO}_{3}$ (up to 


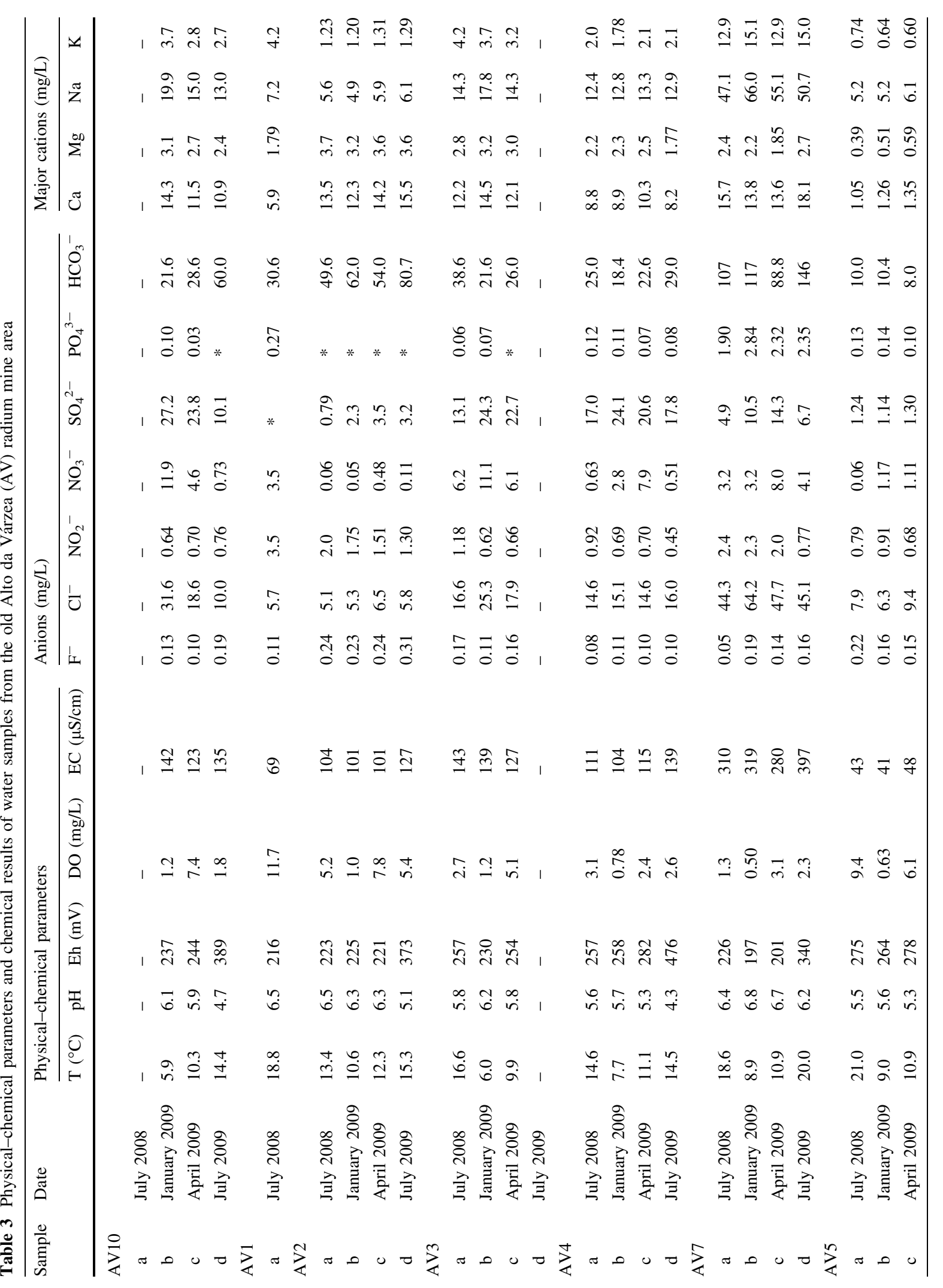




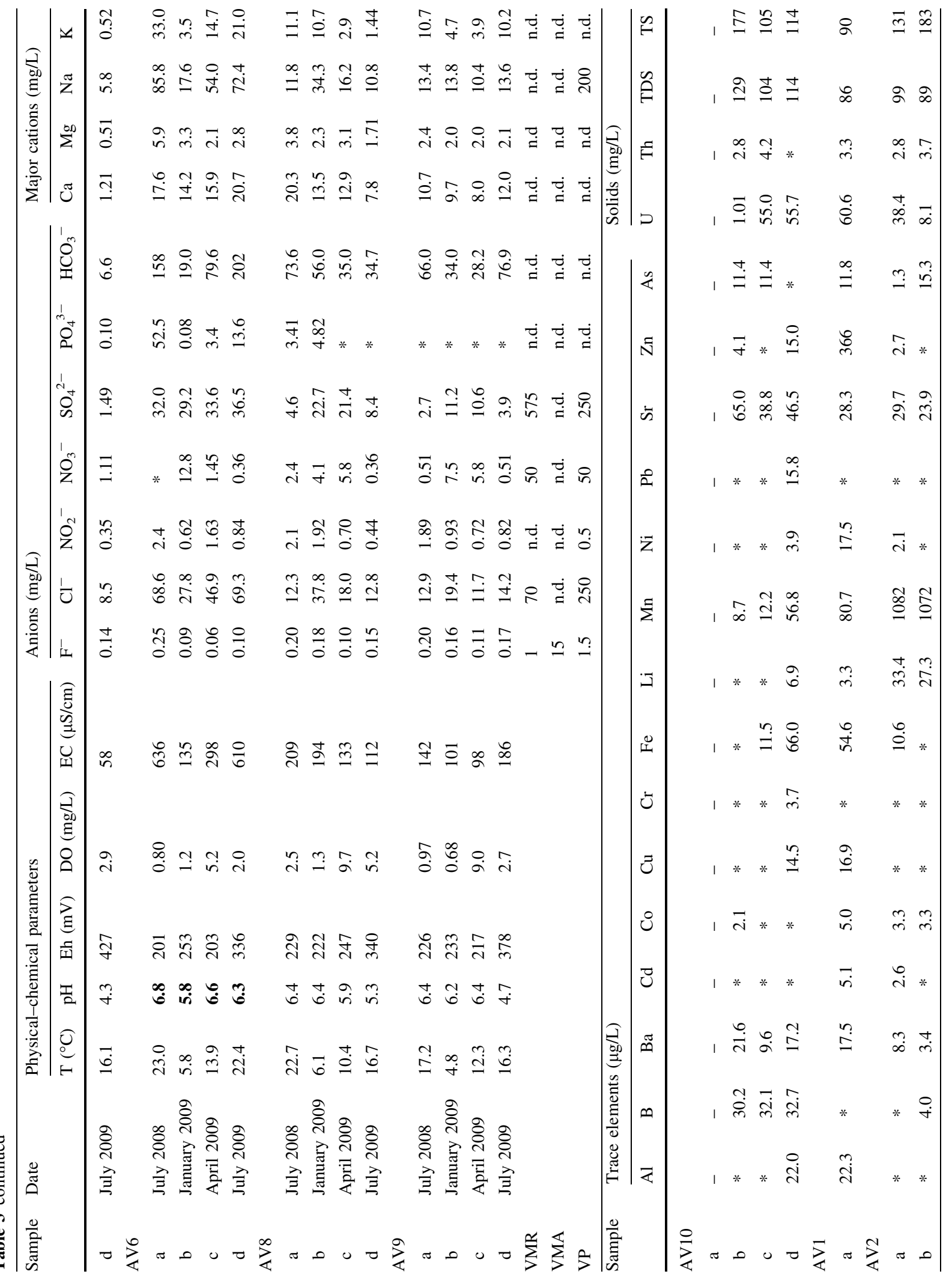




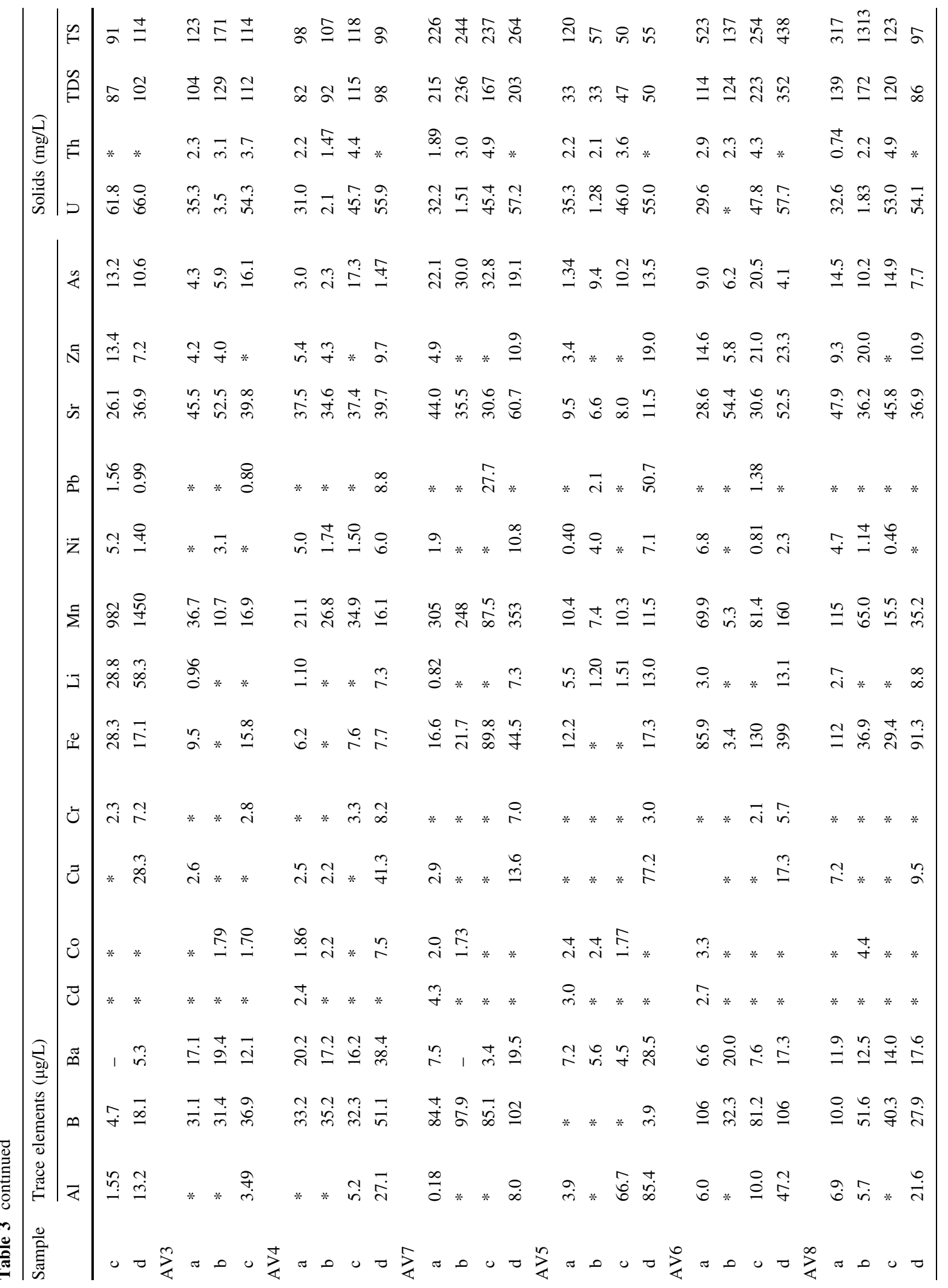




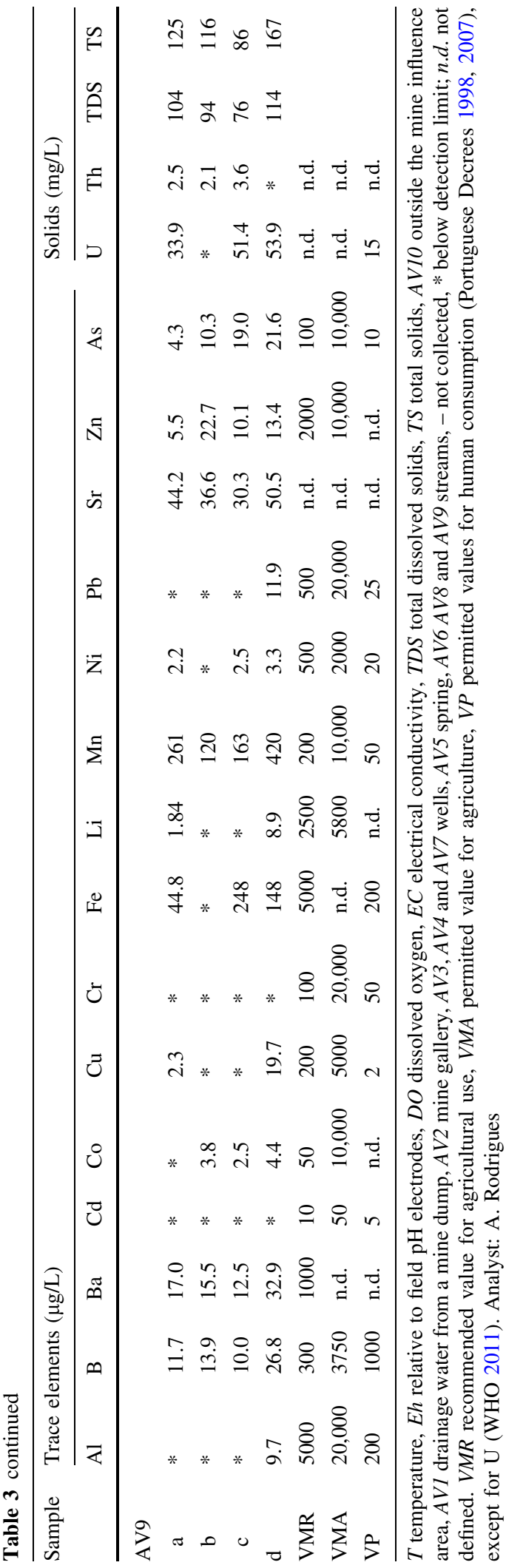

$67.21 \%$ ) also occurs in a significant proportion, due to the high $\mathrm{pH}$ values. In waters with the highest $\mathrm{SO}_{4}{ }^{2-}$ content and most of them with low $\mathrm{pH}$ values, $\mathrm{PbSO}_{4}$ (up to $3.82 \%$ ) also formed (Table 4). In general, in waters with $\mathrm{pH}$ values higher than $6.0, \mathrm{PbCO}_{3}$ (up to $67.21 \%$ ) and $\mathrm{PbOH}^{+}$(up to $1.48 \%$ ) are also present.

Due to the $\mathrm{Na}-\mathrm{HCO}_{3}{ }^{-}$type of water and their $\mathrm{pH}$ values, most species of $\mathrm{Th}$ and $\mathrm{U}$ are $\mathrm{CO}_{3}$ complexes. Thorium occurs predominantly as $\mathrm{Th}(\mathrm{OH})_{3}\left(\mathrm{CO}_{3}\right)^{-}$(up to $64.63 \%$ ), but also as $\mathrm{Th}(\mathrm{OH})_{2}\left(\mathrm{CO}_{3}\right)$ (up to $54.91 \%$ ) and $\mathrm{Th}(\mathrm{OH})_{2}(-$ $\left.\mathrm{CO}_{3}\right)_{2}^{2-}$ (up to $19.06 \%$ ) in waters AV7 (April 2009), AV10 (April 2009), AV7 (April 2009) (Table 4). In the water of the spring AV5 (April 2009) $\mathrm{ThF}_{2}{ }^{2+}$ is predominant $(52.75 \%)$, followed by $\mathrm{ThF}_{3}{ }^{+}(19.77 \%)$. Soluble thorium species are not stable under natural $\mathrm{pH}$ conditions (5-8) which restricts the mobility of thorium. The carbonate concentration increases the formation of soluble complex of carbonate, and those complexes increase the thorium concentration in water. However, they easily form colloids or precipitates (Kim et al. 2010). Thorium (IV) forms strong complexes with humic and fulvic acids, and its adsorption to organic matter, clays and oxides increase with $\mathrm{pH}$, limiting its mobility and bioavailability. The waters AV10 (April 2009), AV1 (July 2009), AV7 (April 2009), AV5 (April 2009) are saturated in crystalline $\mathrm{ThO}_{2}$, which means if the $\mathrm{pH}$ values decrease, more Th can be released into solution (Vandenborre et al. 2008).

The uranyl carbonate complex, $\mathrm{UO}_{2} \mathrm{CO}_{3}$ is the predominant specie in most water samples (up to $91.10 \%$ ) (Table 4). The bicarbonate complexes $\mathrm{UO}_{2}\left(\mathrm{CO}_{3}\right)_{2}^{2-}$ (up to $21.24 \%$ ) occurs in most waters and $\mathrm{UO}_{2}\left(\mathrm{CO}_{3}\right)_{3}^{4-}$ (up to $4.26 \%$ ) also occurs in AV2 (April 2009), AV7 (April and July 2009) and AV6 (April and July 2009). However, $\mathrm{CaUO}_{2}\left(\mathrm{CO}_{3}\right)_{3}^{2-}$ (up to $45.96 \%$ ) and $\mathrm{CaUO}_{2}\left(\mathrm{CO}_{3}\right)_{3}$ (up to $36.56 \%$ ) are also present in samples AV7 and AV6 in both campaigns, April and July 2009, due to their high $\mathrm{Ca}$ content and near neutral $\mathrm{pH}$. Uranium also occurs as $\mathrm{UO}_{2}{ }^{2+}$ (up to $40.63 \%$ ) in samples AV2 (July 2009), AV10 and AV5 (in April and July 2009) (Table 4). The uranyl ion is more typical in waters with $\mathrm{pH}$ values lower than 5.0 and is higher in spring AV5 (July 2009), which has the lowest pH value (4.3) found in waters from the old Alto da Várzea mine (Table 3). 
Fig. 4 Classification of waters from the Alto da Várzea radium mine area in the Ficklin diagram (Ficklin et al. 1992)

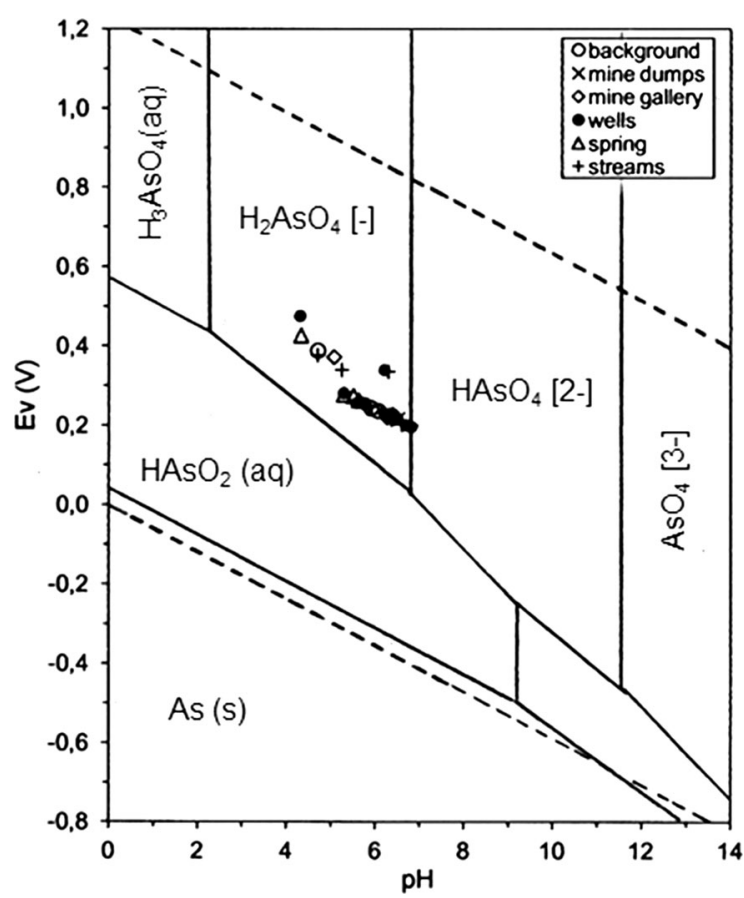

Fig. 5 Eh-pH diagram for the system As-Fe-O-H-S of the waters from the Alto da Várzea radium mine area. Adapted GSJ (2005)

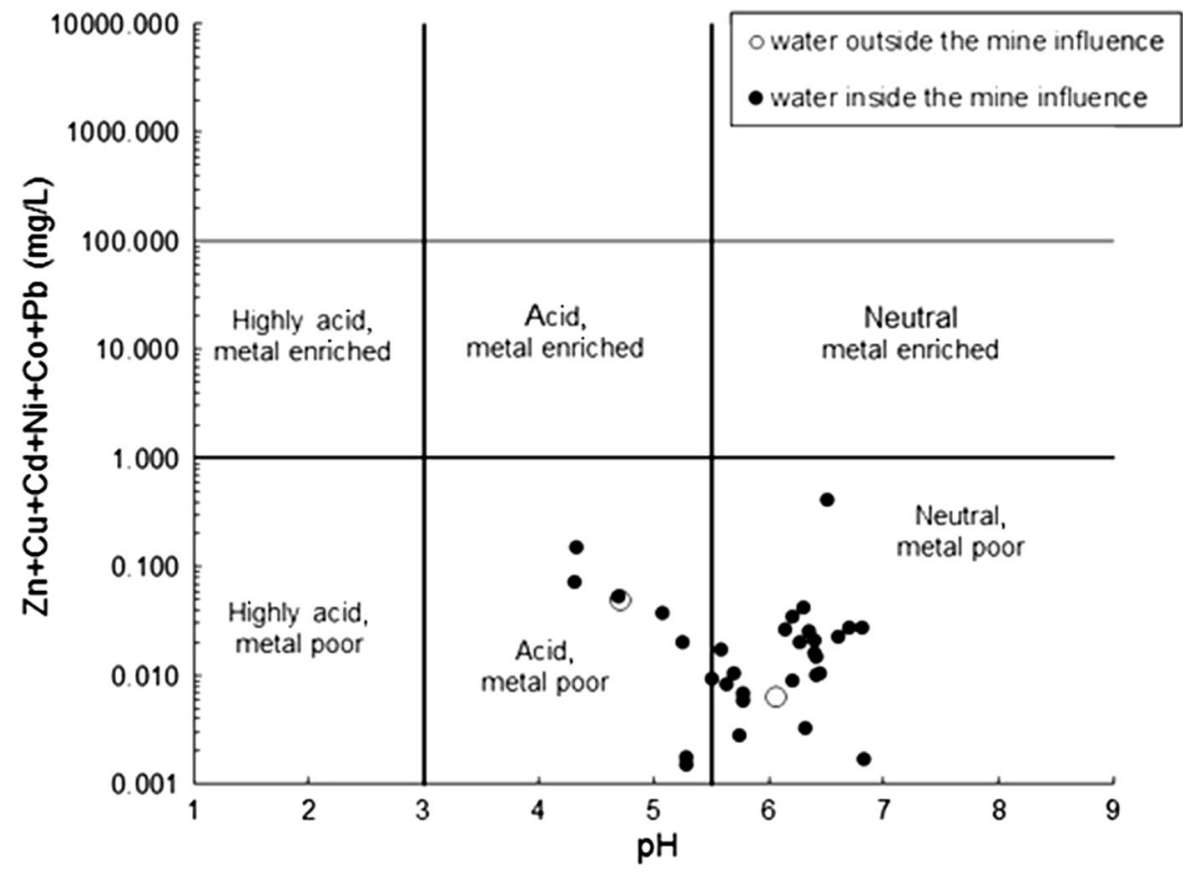

\section{Potentially toxic contamination and relevance to human health}

There are several international evaluation methods of PTEs in the sediments and soils, such as Geoaccumulation Index (IGeo), enrichment factor (EF), Potential Ecological Risk Index (PERI) (e.g.Wenyl et al. 1997; Verca and Dolenec 2005).

The degree of contamination caused by PTEs of stream sediments from the old Alto da Várzea radium mine area is classified by the geoaccumulation index Igeo (Müller 1979). The Igeo $=\log _{2}[\mathrm{Cn} /(1.5), \mathrm{Bn}]$, where $\mathrm{Cn}=$ chemical element concentration $(\mathrm{ppm})$ and $\mathrm{Bn}=$ background levels (ppm). The background values for PTE are the median data from a low density geochemical survey of Portuguese stream sediments (Ferreira 2000; Ferreira et al. 2001). The calculated Igeo for upstream and downstream sediments of the studied area are given in Table 5. These sediments are mainly contaminated in As, Th, U and W. The upstream sediments present As belonging to the class 2-moderately contaminated. But As reaches the class 6-extremely contaminated in downstream sediments. The Th, $\mathrm{U}$ and $\mathrm{W}$ reach the class 4-heavily contaminated in upstream sediments and the class 6 in downstream sediments. Furthermore, Mn reaches the 


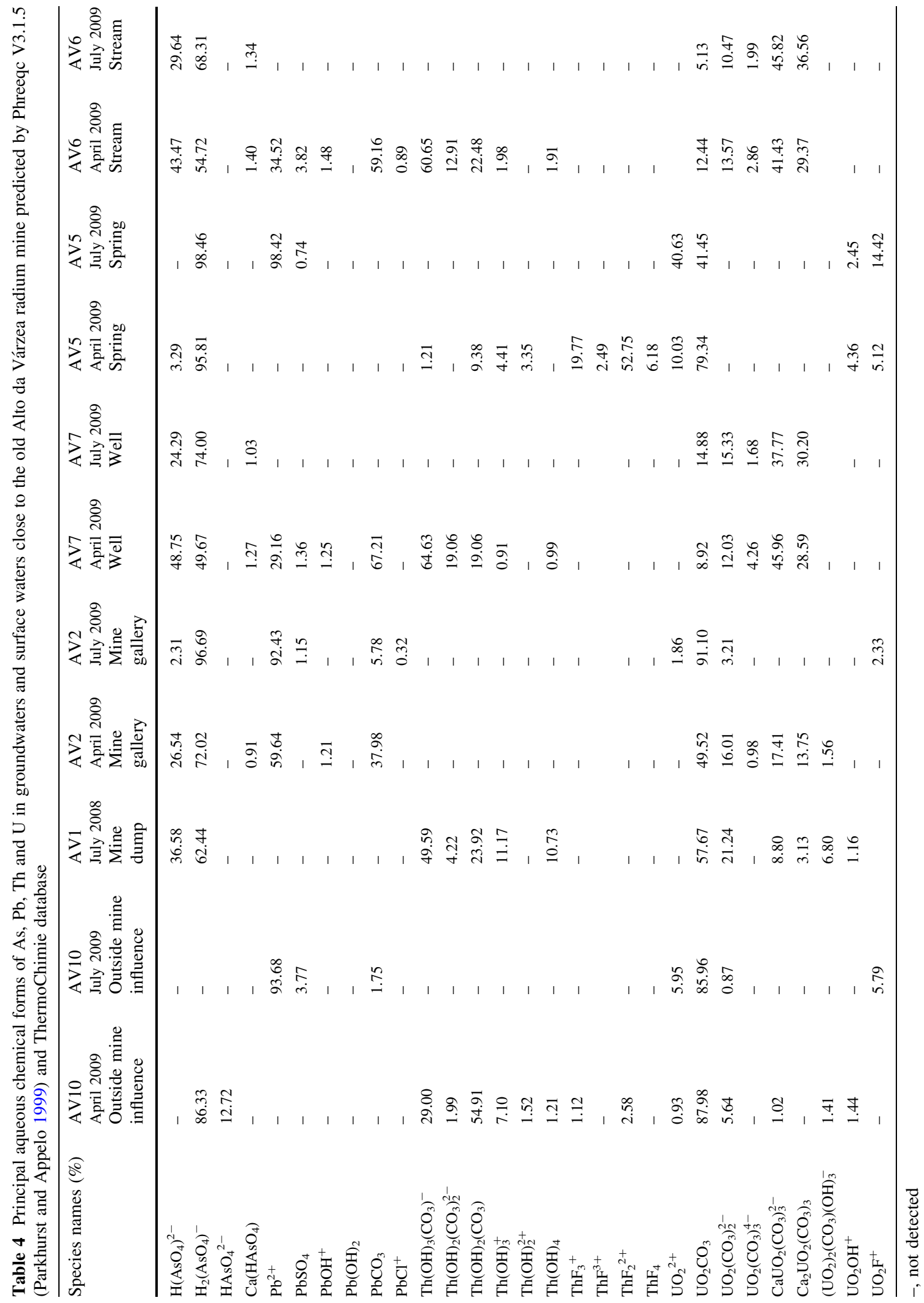


Table 5 Geoaccumulation (Igeo) Index for PTEs in upstream and downstream sediments from the old Alto da Várzea (AV) radium mine area

\begin{tabular}{|c|c|c|c|c|c|c|c|c|c|c|c|c|c|c|c|}
\hline & $\mathrm{Al}$ & $\mathrm{Fe}$ & As & $\mathrm{Co}$ & $\mathrm{Cr}$ & $\mathrm{Cu}$ & $\mathrm{Mn}$ & $\mathrm{Ni}$ & $\mathrm{Pb}$ & $\mathrm{Sb}$ & $\mathrm{Sr}$ & $\mathrm{Th}$ & $\mathrm{U}$ & $\mathrm{W}$ & $\mathrm{Zn}$ \\
\hline \multicolumn{16}{|c|}{ Upstream } \\
\hline SD8 & 0 & 0 & 2 & 0 & 0 & 0 & 0 & 0 & 0 & 1 & 0 & 4 & 4 & 4 & 0 \\
\hline SD9 & 0 & 0 & 2 & 0 & 0 & 0 & 0 & 0 & 0 & 1 & 0 & 4 & 4 & 3 & 0 \\
\hline \multicolumn{16}{|c|}{ Downstream } \\
\hline SD1 & 0 & 0 & 2 & 0 & 0 & 0 & 0 & 0 & 0 & 0 & 0 & 4 & 4 & 3 & 0 \\
\hline SD2 & 0 & 0 & 6 & 0 & 0 & 0 & 3 & 0 & 0 & 0 & 0 & 6 & 8 & 6 & 0 \\
\hline $\mathrm{SD} 2^{+}$ & 0 & 0 & 3 & 0 & 1 & 0 & 4 & 0 & 2 & 0 & 0 & 5 & 8 & 5 & 0 \\
\hline SD4 & 0 & 0 & 3 & 0 & 0 & 0 & 0 & 0 & 0 & 1 & 0 & 4 & 4 & 5 & 0 \\
\hline SD5 & 0 & 0 & 3 & 0 & 0 & 0 & 0 & 0 & 0 & 1 & 0 & 3 & 4 & 3 & 0 \\
\hline \multirow[t]{2}{*}{ SD6 } & 0 & 0 & 2 & 0 & 0 & 0 & 0 & 0 & 0 & 0 & 0 & 4 & 4 & 6 & 0 \\
\hline & & & & & & & Class & & & & & & & & Class \\
\hline
\end{tabular}

Correspondence between Igeo values and Igeo classes according to Müller (1979)

Igeo $\leq 0$ practically uncontaminated $\quad 0 \quad 2<$ Igeo $\leq 3$ moderately to heavily contaminated 3

$0<$ Igeo $\leq 1$ uncontaminated to moderately contaminated $1 \quad 3<$ Igeo $\leq 4$ heavily contaminated 4

$1<$ Igeo $\leq 2$ moderately contaminated $\quad 2 \quad 4<$ Igeo $\leq 5$ heavily to extremely contaminated 5

$5 \leq$ Igeo extremely contaminated 6

Table 6 Enrichment factor (EF) of stream sediments and soils from the Alto da Várzea radium mine area

\begin{tabular}{ccccccccccccccccc}
\hline Sample & $\mathrm{Al}$ & $\mathrm{Fe}$ & $\mathrm{As}$ & $\mathrm{Co}$ & $\mathrm{Cr}$ & $\mathrm{Cu}$ & $\mathrm{Mn}$ & $\mathrm{Ni}$ & $\mathrm{Pb}$ & $\mathrm{Sb}$ & $\mathrm{Sr}$ & $\mathrm{Th}$ & $\mathrm{U}$ & $\mathrm{W}$ & $\mathrm{Zn}$ \\
\hline \multicolumn{2}{l}{ Stream sediments } \\
SD1 & 1.00 & 0.74 & 0.84 & 0.00 & 0.00 & 0.00 & 0.78 & 0.00 & 0.78 & 0.00 & 0.87 & 0.60 & 0.69 & 0.60 & 0.95 \\
SD2 & 1.00 & 1.20 & 9.96 & 0.00 & 0.46 & 0.62 & 15.38 & 0.76 & 1.16 & 0.00 & 1.64 & 3.73 & 14.64 & 3.96 & 0.68 \\
SD2 & 1.00 & 1.19 & 1.34 & 0.00 & 3.76 & 1.11 & 22.78 & 2.27 & 3.12 & 0.00 & 0.24 & 1.04 & 8.03 & 1.07 & 0.73 \\
SD4 & 1.00 & 1.20 & 0.91 & 0.00 & 0.62 & 0.71 & 1.33 & 0.68 & 1.13 & 0.65 & 1.35 & 0.60 & 0.79 & 0.99 & 0.74 \\
SD5 & 1.00 & 1.20 & 0.73 & 0.00 & 0.28 & 0.41 & 0.32 & 0.00 & 0.90 & 0.84 & 0.62 & 0.27 & 0.75 & 0.34 & 0.27 \\
SD6 & 1.00 & 1.21 & 0.96 & 0.00 & 1.59 & 1.36 & 0.93 & 1.08 & 0.96 & 0.00 & 1.29 & 1.06 & 1.08 & 3.54 & 1.34 \\
Soils & & & & & & & & & & & & & & \\
SL3 & 1.00 & 1.13 & 1.24 & 1.74 & 4.23 & 0.55 & 2.00 & 0.98 & 0.86 & 1.09 & 2.06 & 0.98 & 1.72 & 1.38 & 1.75 \\
SL4 & 1.00 & 0.98 & 1.17 & 1.14 & 1.44 & 0.32 & 0.43 & 1.32 & 1.00 & 2.65 & 1.37 & 1.15 & 2.21 & 0.90 & 0.87 \\
SL5 & 1.00 & 1.01 & 0.79 & 1.41 & 1.39 & 0.21 & 0.87 & 1.12 & 0.68 & 1.38 & 1.06 & 1.21 & 0.85 & 1.02 & 0.87 \\
SL7 & 1.00 & 1.30 & 1.93 & 3.83 & 4.36 & 0.75 & 2.01 & 2.49 & 1.67 & 2.43 & 3.23 & 3.27 & 2.18 & 4.18 & 2.35 \\
SL8 & 1.00 & 0.95 & 1.05 & 0.98 & 0.49 & 0.62 & 0.37 & 1.02 & 0.81 & 0.89 & 1.28 & 1.24 & 0.81 & 0.60 & 0.98 \\
\hline
\end{tabular}

$\mathrm{EF}=\left[\left(\mathrm{element}_{\text {sample }} / \mathrm{Al}_{\text {sample }}\right)\right] /\left[\left(\mathrm{element}_{\text {baseline }} / \mathrm{Al}_{\text {baseline }}\right)\right], \mathrm{EF}<2$ is deficiency to minimum enrichment, $\mathrm{EF}=2-5$ is moderate enrichment, $\mathrm{EF}=5-20$ is significant enrichment, $\mathrm{EF}=20-40$ is very high enrichment, $\mathrm{EF}>40$ is extremely high enrichment

class 4 and $\mathrm{Pb}$ reaches the class 2-moderately contaminated in downstream sediments. Therefore, downstream sediments are more contaminated than upstream sediments due to erosion and leaching of mine dumps.
The EF was used to assess the enrichment degree and contamination levels of stream sediments and soils from the mine influence area (Table 6) into five classes (Sutherland 2000; Andrew and Sutherland 2004). The EF values were calculated using the $\mathrm{Al}$ 
concentration as the reference element, because it has a low variation in all stream sediments and soils (average $\mathrm{Al}$ contents: stream sediments $=13.8 \mathrm{mg}$ / $\mathrm{kg}$; soils $=21.5 \mathrm{mg} / \mathrm{kg}$; Table 2). Most stream sediment and soil samples from Alto da Várzea mine area present a deficiency to minimum enrichment for all PTEs $(\mathrm{EF}<2$; Table 6). The stream sediment samples-SD2 and SD2' - are the more PTEs enriched samples showing a moderate enrichment in $\mathrm{Cr}, \mathrm{Ni}, \mathrm{Pb}$, Sr and Th (EF: 2-5; Table 6). These stream sediments also have a significant enrichment in As and U (EF: 5-20; Table 6) and a very high enrichment in Mn (EF: 20-40; Table 6). A stream sediment is also moderately enriched in $\mathrm{Cr}$ and $\mathrm{W}$ (Sample SD6; Table 6). The EF of soil sample SL7 has a moderate enrichment in all PTE (EF: 2-5; Table 6) with exception for $\mathrm{Fe}$ and $\mathrm{Cu}$, while soil sample SL3 also has a moderate enrichment in $\mathrm{Co}, \mathrm{Cr}, \mathrm{Mn}, \mathrm{Sr}, \mathrm{U}$ and Zn. Locally, soil sample SL4 is moderately enriched in $\mathrm{Sb}$ and $\mathrm{U}$ (Table 6).

The EF of PTEs for stream sediments of Alto da Várzea mine increase in the order: $\mathrm{Mn}>\mathrm{U}>\mathrm{As}>$ $\mathrm{W}=\mathrm{Cr}=\mathrm{Th}>\mathrm{Pb}>\mathrm{Ni}=\mathrm{Sr}>\mathrm{Cu}=\mathrm{Zn}=\mathrm{Fe}=$ $\mathrm{Sb}$ and for soil: $\mathrm{Cr}=\mathrm{W}=\mathrm{Co}>\mathrm{Th}=\mathrm{Sr}>\mathrm{Sb}=$ $\mathrm{Ni}=\mathrm{Zn}=\mathrm{U}=\mathrm{Mn}=\mathrm{As}=\mathrm{Pb}>\mathrm{Fe}=\mathrm{U}$ (Table 6), which is mainly associated with the mineralizations of the area and the mobility degree of each PTE. However, the EF can suggest a source for PTEs of the study area, but cannot indicate its chemical activity and biological availability in stream sediments and soils (Guo et al. 2010).

The Potential Ecological Risk Index $\left(E_{\mathrm{f}}^{\mathrm{i}}\right)$ is a parameter of PTE ecological environmental assessment which combines environmental chemistry with biological toxicology and ecology (e.g. Hong et al. 2004; Qinna et al. 2005). The $\mathrm{E}_{\mathrm{f}}^{\mathrm{i}}$ index depends on the pollution index $\left(\mathrm{C}_{\mathrm{f}}^{\mathrm{i}}\right)$ and on the coefficient response for the PTE toxicity $\left(\mathrm{T}_{\mathrm{f}}^{\mathrm{i}}\right)$ and suggests the hazard of a PTE on the human and aquatic ecosystem, reflecting its toxicity and ecological sensitivity (Guo et al. 2010). The calculated ecological risk level of selected PTEs from stream sediments and soils of Alto da Várzea mine area (e.g. As, $\mathrm{Cr}, \mathrm{Cu}, \mathrm{Ni}, \mathrm{Pb}$ and $\mathrm{Zn} ; \mathrm{E}_{\mathrm{f}}^{\mathrm{i}}<40$ ) indicates a low ecological risk and a low grade of potential ecological risk $\left(\mathrm{RI}=\Sigma_{\mathrm{f}}^{\mathrm{i}}<150\right)$ for these PTEs on the studied area.

The median values of $\mathrm{As}, \mathrm{Pb}, \mathrm{Sb}, \mathrm{Th}, \mathrm{U}, \mathrm{W}$ and $\mathrm{Zn}$ of stream sediments from the old Alto da Várzea mine area are higher than those of stream sediments from the European countries (Table 7a). The maximum concentrations of As, Th and $\mathrm{U}$ in stream sediments from the studied area are higher than those of stream sediments from the European countries. The median values of $\mathrm{Fe}, \mathrm{Co}, \mathrm{Cr}, \mathrm{Cu}, \mathrm{Ni}, \mathrm{Th}, \mathrm{U}$ and $\mathrm{W}$ of stream sediments from Alto da Várzea are higher than those of stream sediments from the old Pinhal do Souto uranium mine area (Table 7a). The maximum values of $\mathrm{Fe}, \mathrm{As}, \mathrm{Cr}, \mathrm{Cu}, \mathrm{Mn}, \mathrm{Th}, \mathrm{U}$ and $\mathrm{W}$ of stream sediments from the studied area are higher than those of stream sediments from the Pinhal do Souto area. The Alto da Várzea stream sediments only have a higher $\mathrm{Sb}$ median value, but higher maximum $\mathrm{As}, \mathrm{Mn}$, $\mathrm{Sb}, \mathrm{Th}, \mathrm{U}$ and $\mathrm{W}$ concentrations than those of stream sediments from the old Mondego Sul uranium mine area (Table 7a).

There is no Portuguese legislation with the maximum concentrations of PTE accepted in soil. However, a few indicators designed to approximate the quality of soils are currently available (e.g. Varol 2011; Guillén et al. 2012; Kalender and Uçar 2013). In the studied area, soil contamination was assessed as a function of the contamination factor (CF), calculated as the ratio of the PTE concentration to its background concentration (the median between SL9 and SL10 samples). CF has four contaminated degree classes (Håkanson 1980).

In general, almost soil samples from the old Alto da Várzea mine area are moderately contaminated with Al, Fe, As, Co, Cr, Cu, Mn, Ni, Pb, Sb, Sr, Th, U, W and $\mathrm{Zn}$ (Table 8). The soil samples collected inside mine influence area are considerably contaminated in $\mathrm{Sb}$ and $\mathrm{U}$ (SL4) and Cr and W (SL7). However, soil sample SL3 is the most contaminated with a considerable contamination in $\mathrm{Mn}$ and $\mathrm{Sr}$ and a very high contamination in $\mathrm{Cr}$ (Table 8). The contamination in PTE is directly associated with the radium mines of the area.

The PTE concentrations in soils from the Alto da Várzea radium mine area were compared with the maximum accepted soil levels of the Italian Legislation (Decreto Ministeriale 1999), because there is no Portuguese soil legislation. Arsenic contents of soils from the Alto da Várzea radium mine area collected outside and inside the mine influence, indicating that are contaminated with As and must not be used for any purpose (As $=20 \mathrm{mg} / \mathrm{kg}$ for public, private green areas and residential sites, As $=50 \mathrm{mg} / \mathrm{kg}$ for industrial areas; Fig. 3). This legislation does not give limits for some metals. The $\mathrm{U}$ concentrations of all soil 
Table 7 Comparison of PTE contents ( $\mathrm{mg} / \mathrm{kg}$ ), except Fe $(\%)$, obtained by aqua regia digestion of stream sediments and soils from the old Alto da Várzea radium mine area with those of European Countries and two Portuguese uranium mine areas

\begin{tabular}{|c|c|c|c|c|c|c|c|c|}
\hline & \multicolumn{2}{|c|}{ Alto da Várzea ${ }^{\mathrm{a}}$} & \multicolumn{2}{|c|}{ European countries $^{\mathrm{b}}$} & \multicolumn{2}{|c|}{ Pinhal do Souto $^{c}$} & \multicolumn{2}{|c|}{ Mondego Sul inside the mine area $^{\mathrm{d}}$} \\
\hline & Median & Maximum & Median & Maximum & Median & Maximum & Median & Maximum \\
\hline \multicolumn{9}{|c|}{ (a) Stream sediments } \\
\hline $\mathrm{Fe}$ & 1.4 & 2.5 & 1.96 & 20 & 0.83 & 2.05 & 3.1 & 3.8 \\
\hline As & 57.7 & 515 & 6 & 231 & 89.1 & 194 & 123 & 211 \\
\hline $\mathrm{Co}$ & 1.9 & 4.8 & 8 & 245 & 0 & 15.2 & 12.6 & 47.4 \\
\hline $\mathrm{Cr}$ & 6.2 & 51.6 & 21 & 1748 & 0 & 21.5 & 41.4 & 66.1 \\
\hline $\mathrm{Cu}$ & 11.3 & 23.4 & 14 & 998 & 4.3 & 20.8 & 30.1 & 47.4 \\
\hline $\mathrm{Mn}$ & 234 & 8671 & 452 & 18,898 & 269 & 1243 & 272 & 1652 \\
\hline $\mathrm{Ni}$ & 5.5 & 21.9 & 16 & 1201 & 0 & 98.4 & 28.6 & 53.7 \\
\hline $\mathrm{Pb}$ & 19.2 & 81.1 & 14 & 4880 & 37.2 & 137 & 51.0 & 159 \\
\hline $\mathrm{Sb}$ & 1.6 & 5.5 & 0.615 & 34 & 3.89 & 19.6 & $*$ & 1.87 \\
\hline $\mathrm{Sr}$ & 7.4 & 14.1 & 126 & 1352 & 15.34 & 30.1 & 7.1 & 22.3 \\
\hline Th & 90.7 & 385 & 10 & 253 & 32.6 & 98.4 & 185 & 281 \\
\hline $\mathrm{U}$ & 50.8 & 575 & $2 *$ & 98 & 0 & 35.7 & 92.1 & 266 \\
\hline W & 11.6 & 35.1 & 1.24 & 82 & 0 & 19.8 & 18.4 & 26.5 \\
\hline $\mathrm{Zn}$ & 96.8 & 109 & 60 & 1140 & 100.4 & 234 & 126 & 346 \\
\hline \multicolumn{9}{|c|}{ (b) Soils } \\
\hline $\mathrm{Fe}$ & 15.3 & 20.9 & 2.0 & 15.2 & 8.7 & 15.1 & 2.9 & 6.8 \\
\hline As & 10.4 & 130 & 6.0 & 220 & 94.9 & 196 & 112 & 223 \\
\hline $\mathrm{Co}$ & 4.8 & 6.3 & 7.0 & 260 & 0 & 52.9 & 9.7 & 24.6 \\
\hline $\mathrm{Cr}$ & 9.9 & 22.6 & 22.0 & 2300 & 1.2 & 17.3 & 50.0 & 76.6 \\
\hline $\mathrm{Cu}$ & 15.3 & 29.7 & 12.0 & 240 & 10.4 & 237 & 26.9 & 58.8 \\
\hline $\mathrm{Mn}$ & 459 & 956 & 380 & 6500 & 214 & 6009 & 89.4 & 1134 \\
\hline $\mathrm{Ni}$ & 5.6 & 7.4 & 14.0 & 2600 & 0 & 46.1 & 26.7 & 60.3 \\
\hline $\mathrm{Pb}$ & 33.2 & 40.3 & 15.0 & 890 & 62.2 & 944 & 79.8 & 226 \\
\hline Th & 88.1 & 118 & 7.2 & 75.9 & 26.2 & 47.2 & 156 & 315 \\
\hline $\mathrm{U}$ & 90.8 & 162 & 2.0 & 53.2 & 25.1 & 337 & 115 & 377 \\
\hline W & 9.7 & 17.4 & $<5.0$ & 14.0 & 19.1 & 57.2 & 11.9 & 29.5 \\
\hline $\mathrm{Zn}$ & 89.1 & 141 & 48.0 & 2300 & 92.7 & 347 & 124 & 364 \\
\hline
\end{tabular}

${ }^{\mathrm{a}}$ The studied area, ${ }^{\mathrm{b}}$ Salminen et al. (2005), ${ }^{\mathrm{c}}$ Neiva et al. (2014), ${ }^{\mathrm{d}}$ Neiva et al. (2016a, b)

samples from Alto da Várzea mine area have higher concentrations than $5 \mathrm{mg} / \mathrm{kg}$ (Ribera et al. 1996) and consequently are contaminated in U (Fig. 3). However, almost soils are not contaminated because their PTE contents are below the maximum accepted soil levels.

The median concentrations of $\mathrm{Fe}, \mathrm{As}, \mathrm{Cu}, \mathrm{Mn}, \mathrm{Pb}$, Th, U, W and Zn of soils from the Alto da Várzea area are higher than those of median concentrations, respectively, of soils from European Countries (Salminen et al. 2005), but lower than their $\mathrm{Co}, \mathrm{Cr}$ and $\mathrm{Ni}$ median contents. The maximum soils concentration obtained for Fe, Th, $\mathrm{U}$ and $\mathrm{W}$ are also higher than, respectively, concentrations of European Countries (Table 7b).

The median values of $\mathrm{Fe}, \mathrm{Co}, \mathrm{Cr}, \mathrm{Cu}, \mathrm{Mn}, \mathrm{Ni}$, Th and $\mathrm{U}$ and the maximum contents of $\mathrm{Fe}, \mathrm{Cr}$ and $\mathrm{Th}$ of soils from Alto da Várzea mine area are higher than those of median values and maximum values contents, respectively, of soils from the old Pinhal do Souto uranium mine area (Table $7 b$ ). The median soil values of $\mathrm{Fe}$ and $\mathrm{Mn}$ and maximum value of $\mathrm{Mn}$ from the studied area are higher than those of soils from the Mondego Sul uranium mine area (Table $7 \mathrm{~b}$ ). 
Table 8 Contamination factor $(\mathrm{CF})$ of soils from the Alto da Várzea radium mine area

\begin{tabular}{cccccccccccccccccc}
\hline Sample & $\mathrm{pH}$ & $\mathrm{EC}$ & $\mathrm{Al}$ & $\mathrm{Fe}$ & $\mathrm{As}$ & $\mathrm{Co}$ & $\mathrm{Cr}$ & $\mathrm{Cu}$ & $\mathrm{Mn}$ & $\mathrm{Ni}$ & $\mathrm{Pb}$ & $\mathrm{Sb}$ & $\mathrm{Sr}$ & $\mathrm{Th}$ & $\mathrm{U}$ & $\mathrm{W}$ & $\mathrm{Zn}$ \\
\hline AVSL3 & 1 & 2 & 1 & 1 & 2 & 2 & 6 & 1 & 3 & 1 & 1 & 1 & 3 & 1 & 2 & 2 & 2 \\
AVSL4 & 1 & 2 & 1 & 1 & 2 & 1 & 2 & 0 & 1 & 2 & 1 & 3 & 2 & 2 & 3 & 1 & 1 \\
AVSL5 & 1 & 1 & 2 & 2 & 1 & 2 & 2 & 0 & 2 & 2 & 1 & 2 & 2 & 2 & 1 & 2 & 2 \\
AVSL7 & 1 & 2 & 1 & 1 & 1 & 2 & 3 & 0 & 1 & 2 & 1 & 2 & 2 & 2 & 1 & 3 & 2 \\
AVSL8 & 1 & 1 & 2 & 2 & 1 & 2 & 2 & 1 & 1 & 2 & 1 & 2 & 2 & 2 & 1 & 1 & 2 \\
\hline
\end{tabular}

$\mathrm{CF}=\left(\right.$ element $_{\text {sample }} /$ element $\left._{\text {background }}\right) ; \quad \mathrm{CF}<1$-low contamination; $1<\mathrm{CF}<3$-moderate contamination; $3<\mathrm{CF}<6-$ considerable contamination; $\mathrm{CF}>6$-very high contamination
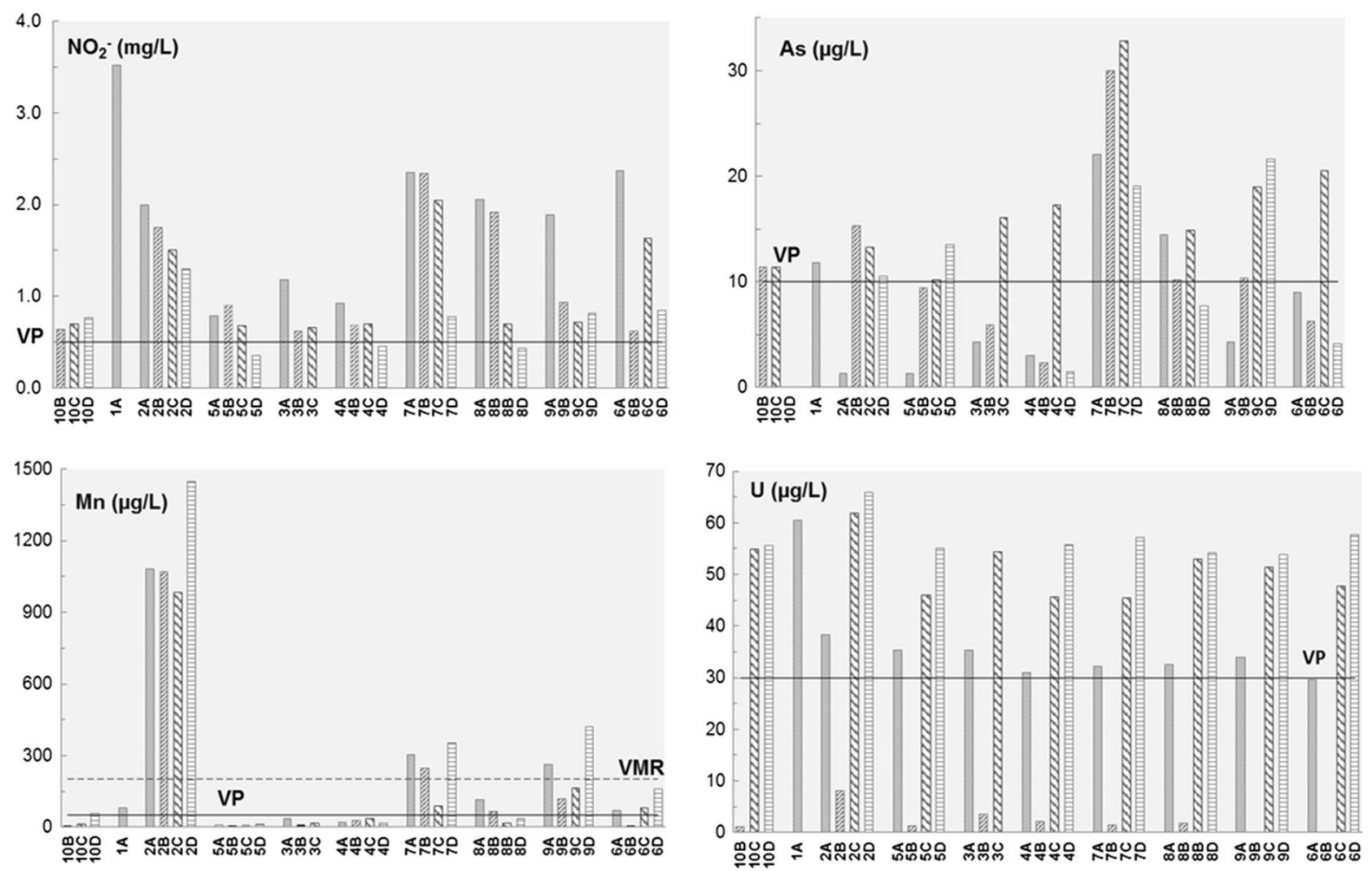

Fig. 6 Seasonal chemical variations in waters from the Alto da Várzea radium mine area. Waters collected during: A July 2008; $B$ January 2009; C April 2009; D July 2009. VMR recommended

To assess the water quality from the Alto da Várzea mine, the guideline values for drinking water quality proposed by the Portuguese legislation (Portuguese Decree 1998, 2007) and the World Health Organization (WHO 2011) were used. Most water samples from the Alto da Várzea mine area are contaminated $\mathrm{NO}_{2}{ }^{-}, \mathrm{Mn}, \mathrm{Cu}, \mathrm{As}, \mathrm{Pb}$ and $\mathrm{U}$ and must not be used for human consumption (Fig. 6; Table 3). Iron water contents above $0.3 \mathrm{mg} / \mathrm{L}$

values for agriculture, VP permitted values for human consumption (Portuguese Decrees 1998, 2007), except for U (WHO 2011)

(WHO 2011) will affect the organoleptic water properties which occurred in most water samples from the Alto da Várzea mine area (Table 3). Arsenic is a PTE to human health and mining activities are considered to be one of the sources of As in surface water and groundwater (e.g. Mukherjee et al. 2011; Hiller et al. 2012; Antunes and Albuquerque 2013; Carvalho et al. 2014; Neiva et al. 2014; Antunes et al. 2016). 
Some water samples (AV2; AV7 and AV9) are also contaminated in $\mathrm{Mn}$ and must not be used for agricultural activities (Fig. 6). All waters present a suspended solids content above the recommended values by Portuguese Legislation ( $25 \mathrm{mg} / \mathrm{L}$; Table 3 ) which could be associated with the suspension of Fe oxyhydroxides in waters which was suggested by the turbid water and algae proliferation, particularly in the stream water samples (AV6 and AV8; Table 3). Suspended matter in water affects the quality of aquatic life and causes ecological degradation, increasing the costs of water treatment (Bilotta et al. 2012).

The isotopic $\mathrm{Ra}^{226}$ contents of waters associated with the AV mine range between 0.050 and $0.145 \mathrm{~Bq} /$ $\mathrm{L}$ and are below the legislation defined value (EDM 2005).

\section{Conclusions}

The abandoned Alto da Várzea radium mines and associated dumps and tailings, containing the secondary U-minerals autunite and torbernite, are responsible for the stream sediment, soil and water contamination in potentially toxic elements (PTE).

The stream sediments receiving the influence of the mine area contain higher PTE contents than background sediments. These sediments are mainly contaminated in As, Th, U and W. However, they are mainly moderately contaminated in most of PTE because are adsorbed by Fe-oxyhydroxides.

The soils collected inside mine influence, contain the highest $\mathrm{EC}$ values and $\mathrm{As}, \mathrm{Co}, \mathrm{Cr}, \mathrm{Sr}$, Th, U, W and $\mathrm{Zn}$, because PTE were released from the mine dumps and retained in the closest soils. Arsenic and U soil contents are above the referenced values of the Italian legislation. Therefore, the soils are contaminated with As and $\mathrm{U}$ and must not be used for any purpose. The soils are moderately contaminated with the other PTE, which are below the maximum accepted soil levels, suggesting a low contamination. The contamination in PTE is directly associated with the radium mines of the area.

The waters from the Alto da Várzea mine area are acid to neutral $(\mathrm{pH} 4.3-6.8)$ with more acidic values during summer than winter. The acidic waters resulted of sulphides oxidation from the mineralized veins and consequently from tailings and dumps.
Arsenic mainly occurs as pentavalent species $\left(\mathrm{H}_{2}\left(\mathrm{AsO}_{4}\right)^{-}\right.$and $\left(\mathrm{H}\left(\mathrm{AsO}_{4}\right)^{2-}\right)$, reducing its mobility from waters to soils and stream sediments. The saturation in oxyhydroxides of waters favoured the adsorption of arsenic to these oxyhydroxides, suggesting that the high contents of As in soils and stream sediments are due to the aquatic transport of colloids or by the mechanical transport of arsenic from tailings. Lead is predominantly in divalent form (up to $98.42 \%$ ), mainly in waters collected in the warm season (July 2009) from outside and inside mine influence. Therefore, $\mathrm{Pb}$ has a higher mobility in waters during the summer. $\mathrm{PbSO}_{4}$ also occurs in waters with a high $\mathrm{SO}_{4}{ }^{2-}$ content and generally in those with the lowest $\mathrm{pH}$ values. Thorium occurs mainly as hydroxide-carbonate complexes, due to the $\mathrm{Na}-\mathrm{HCO}_{3}{ }^{-}$type of waters from Alto da Várzea. Despite these complexes increase the Th concentration in waters by dissolution of $\mathrm{ThO}_{2}$, they easily form colloids or precipitated, being unstable in any physical-chemical conditions. If $\mathrm{pH}$ values decrease, more Th can be in solution, by dissolution of $\mathrm{ThO}_{2}$, in which most waters are saturated. The $\mathrm{UO}_{2} \mathrm{CO}_{3}$ is predominant in the waters and decreases the mobility of $U$ in waters. However, in waters from the mine gallery and spring with the lowest $\mathrm{pH}$, uranyl ions were formed, increasing their mobility and spreading in the water system.

Most waters are contaminated in $\mathrm{NO}_{2}{ }^{-}, \mathrm{Mn}, \mathrm{Cu}$, $\mathrm{As}, \mathrm{Pb}$ and $\mathrm{U}$ and must not be used for human consumption and some of them in agricultural activities. In general, there is a decrease in $\mathrm{U}$ contents from summer to winter, probably due to a dilution effect. There is not a significant seasonal variation in the major ion concentrations and PTEs of the studied waters. All waters present a suspended solid content above the recommended values, affecting the quality of aquatic life and causing ecological degradation.

Arsenic is a PTE to human health and mining activities are considered to be one of the sources of As in stream sediments, soils, surface and groundwater. The obtained results in the studied area reinforce the evidence of environmental and human health risks associated with old abandoned mining areas and the definition and application of adequate remediation methodologies. The contaminated water, stream sediment and soil from the study area must be remediated, such should be suggested to another abandoned radium mines. 
Acknowledgements Thanks are due to Prof. João Coutinho for the determination of organic matter and cation exchange capacity in samples of stream sediments and soils and A. Rodrigues for the water analyses, EDM for some information on the Alto da Várzea mine area. This study had the support of Portuguese Fundação para a Ciência e Tecnologia (FCT), through the strategic projects UID/GEO/04035/2013 and UID/ MAR/04292/2013 (MARE).

\section{References}

Acosta, J. A., Faz, A., Martinez, S., Zornoza, R., Carmona, D. M., \& Kabas, S. (2011). Multivariate statistical and GISbased approach to evaluate heavy metals behavior in mine sites for future reclamation. Journal Geochemical Exploration, 109, 8-17.

Albuquerque, M. T. D., \& Antunes, I. M. H. R. (2015). Uranium Spatio-temporal variability in groundwater-An environmental risk assessment case study. In J. R. Nelson (Ed.), Uranium: Sources, exposure and environmental effects; Chapter 7 (pp. 145-147). New York: Nova Publishers. ISBN 978-1-63482-827-7 (e-book).

Alloway, J. (1995). Heavy metals in soils (2nd ed., p. 368). London: Blackie Academic \& Professional.

ANDRA. (2009). ThermoChimie version 7b, C.RP.ASTR. O4.0032.

Andrew, S., \& Sutherland, R. A. (2004). Cu, Pb and Zn contamination in Nuuanu Watershed, Oahu, Hawaii. Science Total Environment, 324, 173-182.

Antunes, I. M. H. R., \& Albuquerque, M. T. D. (2013). Using indicator kriging for the evaluation of arsenic potential contamination in an abandoned mining area (Portugal). Science Total Environment, 442, 545-552.

Antunes, I. M. H. R., Gomes, M. E. P., Neiva, A. M. R., Carvalho, P. C. S., \& Santos, A. C. T. (2016). Potential risk assessment in stream sediments, soils and waters after remediation in an abandoned $\mathrm{W}>$ Sn mine (NE Portugal). Ecotoxicology and Environmental Safety, 133, 135-145.

Bilotta, G. S., Burnside, N. G., Cheek, L., Dunbar, M. J., Grove, M. K., Harrison, C., et al. (2012). Developing environmentspecific water quality guidelines for suspended particulate matter. Water Research, 46, 2324-2332.

Boularbah, A., Schwartz, C., Bitton, G., \& Morel, J. L. (2006). Heavy metal contamination from mining sites in south Morocco. 1. Use of a biotest to assess metal toxicity of tailings and soils. Chemosphere, 63, 802-810.

Cabral Pinto, M. M. S., Silva, M. M. V. G., \& Neiva, A. M. R. (2008). Geochemistry of U-bearing minerals from the Vale de Abrutiga uranium mine area, central Portugal. Neues Jahrbuch Mineralogie, 185, 183-198.

Cabral Pinto, M. M. S., Silva, M. M. V. G., \& Neiva, A. M. R. (2009). Uranium minerals from a Portuguese Variscan peraluminous granite, its alteration, and related uraniumquartz veins. In G. H. Wolfe (Ed.), Uranium: Compounds, isotopes and applications (pp. 287-318). New York: Nova Science.

Cardoso, J. C., Bessa, M. T., \& Marado, M. B. (1973). Carta dos Solos de Portugal (1:1000000).
Carvalho, F. P. (2014). The national radioactivity monitoring program for the regions of uranium mines and uranium legacy sites in Portugal. Procedia Earth and Planetary Science, 8, 33-37.

Carvalho, P. C. S., Neiva, A. M. R., \& Silva, M. M. V. G. (2012). Assessment to the potential mobility and toxicity of metals and metalloids in soils contaminated by old Sb-Au and AsAu mines (NW Portugal). Environmental Earth Sciences, 65, 1215-1230.

Carvalho, P. C. S., Neiva, A. M. R., Silva, M. M. V. G., \& Antunes I. M. H. R. (2013). Metal and metalloid leaching from tailings into stream water and sediments in the old $\mathrm{Ag}-\mathrm{Pb}-\mathrm{Zn}$ Terramonte mine, northern Portugal. Environmental Earth Sciences, 71(5), 2029-2041.

Carvalho, P. C. S., Neiva, A. M. R., Silva, M. M. V. G., \& Ferreira da Silva, E. A. (2014). Geochemical comparison of waters and stream sediments close to abandoned $\mathrm{Sb}-\mathrm{Au}$ and As-Au mining areas, northern Portugal. Chemie der Erde, 74(2), 267-283.

Cui, Y., \& Xin, D. (2011). Soil heavy metal and wheat phytotoxicity in the vicinity of an abandoned lead-zinc mine in Shangyu City, eastern China. Environmental Earth Sciences, 62, 257-264.

Decreto Ministeriale. (1999). Approvazione dei metodi ufficiali di analise chimica del suolo. SO Gazzetta Ufficiale.

Empresa de Desenvolvimento Mineiro (EDM). (2005). Mina do Alto da Várzea-Relatório Final.

European Environment Agency. (2006). CLC 2006-Corine Land Cover, Raster data on land cover. Version 12/ 2009.

Favas, P. J. C., Pratas, J., Gomez, M. E. P., \& Cala, V. (2011). Selective chemical extraction of heavy metals in tailings and soils contaminated by mining activity. Journal Geochemical Exploration, 111, 160-171.

Fernandez-Caliani, J. C., Barba-Brioso, C., Gonzalez, I., \& Galan, E. (2009). Heavy metal pollution in soils around the abandoned mine sites of the Iberian Pyrite Belt (southwest Spain). Water Air Soil Pollution, 200, 211226.

Ferreira, A. M. P. J. (2000). Dados geoquímicos de base de sedimentos fluviais de amostragem de baixa densidade de Portugal Continental: Estudo de factores de variação regional. Unpublished Ph.D. thesis, Univ. Aveiro, Portugal.

Ferreira da Silva, E., Zhang, C., Serrano Pinto, L., Patinha, C., \& Reis, P. (2004). Hazard assessment on arsenic and lead in soils of Castromil gold mining area, Portugal. Applied Geochemistry, 19, 887-898.

Ferreira, A., Inácio, M. M., Morgado, P., Batista, M. J., Ferreira, L., Pereira, V., et al. (2001). Low-density geochemical mapping in Portugal. Applied Geochemistry, 16, 1323-1331.

Ficklin, W. H., Plumlee, G. S., Smith, K. S., \& McHugh, J. B. (1992). Geochemical classification of mine drainage and natural drainage in mineralized areas. In Y. K. Kharaka \& A. S. Maest (Eds.), Water-rock interaction (Vol. 7, pp. 81-384). Rotterdam: Balkema.

Forghani, G., Mokhtarib, A. R., Kazemia, G. A., \& Farda, M. D. (2015). Total concentration, speciation and mobility of potentially toxic elements in soils around a mining area in central Iran. Chemie der Erde, 75, 323-334. 
GSJ. (2005). Atlas of Eh-pH diagrams. Intercomparison of thermodynamic databases. Geologica Survey of Japan, Open File Report No. 419.

Guillén, M. T., Delgado, J., Albanese, S., \& De Vivo, B. (2012). Heavy metals fractionation and multivariate statistical techniques to evaluate the environmental risk in soils of Huelva Township (SW Iberian Peninsula). Journal Geochemical Exploration, 119(120), 32-43.

Guo, W., Liu, X., Liu, Z., \& Li, G. (2010). Pollution and potential ecological risk evaluation of heavy metals in the sediments around Dongjiang Harbor, Tianjin. Procedia Environmental Science, 2, 729-736.

Håkanson, L. (1980). An ecological risk index for aquatic pollution control-A sedimentological approach. Water Research, 14(8), 975-1001.

Hiller, E., Lalinská, B., Chovan, M., Jurkovič, L., Klimko, T., Jankulár, M., et al. (2012). Arsenic and antimony contamination of waters, stream sediments and soils in the vicinity of abandoned antimony mines in the Western Carpathians, Slovakia. Applied Geochemistry, 27, 598-614.

Hong, H., Yajuan, Y., \& Xiaodong, W. (2004). Pollution of heavy metals in surface sediments from Huaihe River (Jiangsu Section) and its assessment of potential ecological risk. Environment Pollution Control, 26(3), 115-118.

Hughes, M. F., Beck, B. D., Chen, Y., Lewis, A. S., \& Thomas, D. J. (2011). Arsenic exposure and toxicology: a historical perspective. Toxicology Science, 123(2), 305-332.

Instituto Português do Mar e da Atmosfera (IPMA). (2015). Clima de Portugal continental. https://www.ipma.pt/pt/ educativa/tempo.clima/.

Kalender, L., \& Uçar, S. Ç. (2013). Assessment of metal contamination in sediments in the tributaries of the Euphrates River, using pollution indices and the determination of the pollution source, Turkey. Journal Geochemical Exploration, 134, 73-84.

Kim, S. S., Baik, M. H., Choi, J. W., Shin, H. S., \& Yun, J. I. (2010). The dissolution of $\mathrm{ThO}_{2}(\mathrm{Cr})$ in carbonate solutions and a granitic groundwater. Journal Radioanalytical and Nuclear Chemistry, 286, 91-97.

Larios, R., Fernández-Martinéz, R., Álvarez, R., \& Rucandio, I. (2012). Arsenic pollution and fractionation in sediments and mine waste samples from different mine sites. Science Total Environment, 431, 426-435.

Larson, L. N., Kipp, G. G., Mott, H. V., \& Stone, J. J. (2012). Sediment pore-water interactions associated with arsenic and uranium transport from the North Cave Hills mining region, South Dakota, USA. Applied Geochemistry, 27, 879-891.

Mamindy-Pajany, Y., Hurel, C., Marmier, N., \& Roméo, M. (2009). Arsenic Adsorption onto Hematite and Goethite. Comptes Rendus Chimie, 12(8), 1-30.

Min, L., Xiaohuan, X., Guiyi, X., Hangxin, C., Zhongfang, Y., Guohua, Z., et al. (2014). National multi-purpose regional geochemical survey in China. Journal Geochemical Exploration, 139, 21-30.

Mukherjee, A., Bhattacharya, P., \& Fryar, A. E. (2011). Arsenic and other toxic elements in surface and groundwater systems. Applied Geochemistry, 26, 415-420.

Müller, S. N. (1979). In: Den sediment des Rheins-Veranderungen seilt (1971). Unschau, 79, 778-783.
Neiva, A. M. R., Antunes, I. M. H. R., Carvalho, P. C. S., \& Santos, A. C. T. (2016a). Uranium and arsenic contamination in the former Mondego Sul uranium mine area, Central Portugal. Journal Geochemical Exploration, 162, $1-15$.

Neiva, A. M. R., Carvalho, P. C. S., Antunes, I. M. H. R., Cabral Pinto, M. M. S., Santos, A. C. T., Cunha, P. P., et al. (2016b). Spatial variability of soils and stream sediments and the remediation effects in a Portuguese uranium mine area. Central Portugal. Chemie Erde Geochemistry. doi:10. 1016/j.chemer.2016.08.033.

Neiva, A. M. R., Carvalho, P. C. S., Antunes, I. M. H. R., Santos, A. C. T., \& Cabral-Pinto, M. M. S. (2015). Spatial and temporal variability of surface water and groundwater before and after remediation of a Portuguese uranium mine area. Chemie der Erde Geochemistry, 75(3), 345-356.

Neiva, A. M. R., Carvalho, P. C. S., Antunes, I. M. H. R., Silva, M. M. V. G., Santos, A. C. T., Cabral Pinto, M. M. S., et al. (2014). Contaminated water, stream sediments and soils close to the abandoned Pinhal do Souto uranium mine, Central Portugal. Journal Geochemical Exploration, 136, 102-117.

Nelson, D. W., \& Sommers, L. E. (1996). Total carbon, organic carbon, and organic matter. In Page et al. (Eds.), Methods of soils analysis, Part 2, 2nd ed. Agronomy, 9 (pp. 961-1010). Madison, WI: American Society of Agronomy Inc.

Parkhurst, D. L., \& Appelo, C. A. J. (2013). Description of input and examples for PHREEQC version 3-A computer program for speciation, batch-reaction, one-dimensional transport, and inverse geochemical calculations. U.S. Geological Survey Techniques and Methods, book 6, chap. A43.

Pinto, M. M. S. C., Silva, M. M. V. G., \& Neiva, A. M. R. (2004). Pollution of water and stream sediments associated with the Vale de Abrutiga uranium mine, Central Portugal. Mine Water Environment, 23, 66-75.

Portuguese Decree. (1998). Decree 236/1998. Portuguese legislation on water quality. Diário da República I-A (pp. 3676-3722).

Portuguese Decree. (2007). Portuguese legislation on water quality. Diário da República I-A (pp. 5747-5765).

Qinna, Z., Qixin, X., \& Kai, Y. (2005). Application of potential ecological risk index in soil pollution of typical polluting industries. Journal of East China Normal University, 1, 110-115.

Ribera, D., Labrot, F., Tisnerat, G., \& Narbonne, J. F. (1996). Uranium in the environment: Occurrence, transfer and biological effects. Environmental Contamination and Toxicology, 146, 53-80.

Salminen, R., Batista, M. J., Bidovec, M., Demetriades, A., De Vivo, B., De Vos W., et al. (2005). Foregs geochemical atlas of Europe. Methodology and Maps, Part 1 (526 pp) and Part 2 (690 pp).

Siegel, F. R. (2002). Environmental geochemistry of potentially toxic metals (p. 218). Berlin: Springer.

SNIRH. (2009). Sistema Nacional de Informação de Recursos Hídricos.

Sutherland, R. A. (2000). Bed sediment-associated trace metals in an urban stream. Oahu, Hawaii. Environmental Geology, 39, 611-627.

Thomas, G. W. (1982). Exchangeable cations. In: A. L. Page (Ed.), Methods of soil analysis, part 2, 2nd edn. 
Vandenborre, J., Abdelouas, A., \& Grambow, B. (2008). Discrepancies in thorium oxide solubility values: A new experimental approach to improve understanding of oxide surface at solid/solution interface. Radiochimica Acta, 96, 515-520.

Varol, M. (2011). Assessment of heavy metal contamination in sediments of the Tigris River (Turkey) using pollution indices and multivariate statistical techniques. Journal Hazards Materials, 195, 355-364.

Verca, P., \& Dolenec, T. (2005). Geochemical estimation of copper contamination in the Healing Mud from Makirina Bay, Central Adriatic. Environmental International, 31(1), 53-61.
Vrhovnik, P., Šmuc, N. R., Dolenec, T., Serafimovski, T., \& Dolenec, M. (2013). An evaluation of trace metal distribution and environmental risk in sediments from the Lake Kalimanci (FYR Macedonia). Environmental Earth Sciences, 70, 761-775.

Wenyl, H., Fengru, H., \& Jingsheng, C. (1997). Comparative study of assessment method for river particulate heavy metal pollution. Science Geography Sin., 17(1), 81-86.

World Health Organization (WHO). (2011). Guidelines for drinking water quality, 4th edn. http://Whqlibdoc.Who.int/ publications/2011/9789241548151_eng.pdf.

Xuejing, X. (1995). Analytical requirements in international geochemical mapping. Analyst, 120, 1497-1504. 